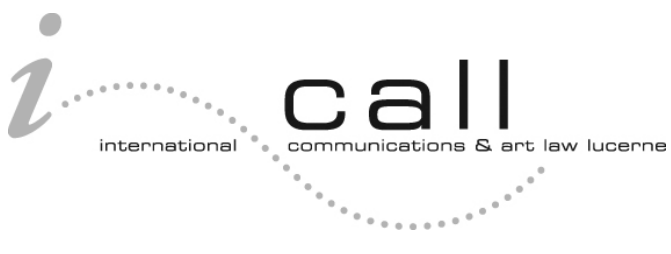

No. $2012 / 02$

\title{
Māori Traditional Cultural Expressions and the Wai 262 Report: Looking at the Details
}

\author{
Jessica Christine Lai*
}

JANUARY 2012

\begin{abstract}
On 2 July 2011, the Waitangi Tribunal delivered the Wai 262 report to the New Zealand Government. After 20 years of deliberation, the report is monumental in both substance and symbolism. Making recommendations as to the place of Māori culture in New Zealand, as guaranteed by Article 2 of the Treaty of Waitangi, the report has the potential to change how Māori cultural heritage is used in the future, including with regard to research practice, trade and intellectual property rights. This paper analyses the recommendations made over traditional cultural expressions, including fixed and non-fixed forms (taonga works), the related traditional knowledge (mātauranga Māori) and hybrid uses of Māori motifs (taonga-derived work). In doing so, it attempts to address and fill in the details left out by the Tribunal. This is followed by a discussion on whether the recommendations are compliant with New Zealand's international obligations.
\end{abstract}

\section{KEY WORDS}

Wai 262, Māori cultural heritage, cultural intellectual property rights, traditional cultural expressions, taonga works, mātauranga Māori.

\footnotetext{
* Jessica Christine Lai is a research fellow, working on the IT ICH (International Trade of Indigenous Cultural Heritage) project, and a member of the i-call (International Communications and Art Law Lucerne) research centre, at the University of Lucerne. Contact at jessica.lai@unilu.ch. The author would like to thank Christoph B. Graber and Susy Frankel for their comments and Angela Hefti for her editorial assistance. The support from the Swiss National Science Foundation is gratefully appreciated.
}

I-CALL WORKING PAPERS are the result of research that takes place through the i-call research centre. The papers have been peer-reviewed.

Suggested CitAtion: Lai, Jessica Christine, 'Māori Traditional Cultural Expressions and the Wai 262 Report: Looking at the Details', University of Lucerne, Switzerland, i-call Working Paper No. 02 (2012). 
Published by:

i-call, The Research Centre for International Communications and Art Law at the University of Lucerne

Frohburgstrasse 3

P.O. Box 4466

6002 Lucerne

Switzerland

ISSN 1664-0144

(C) The i-call Research Centre, Switzerland

All rights reserved. No part of this publication may be reproduced, stored in a retrieval system, or transmitted in any form or by any means, mechanical, photocopying, recording or otherwise, without prior written permission of the publisher.

Permission to use this content must be obtained from the copyright owner. 


\section{MĀORI TRADITIONAL CULTURAL EXPRESSIONS AND THE WAI 262 REPORT: LOOKING AT THE DETAILS}

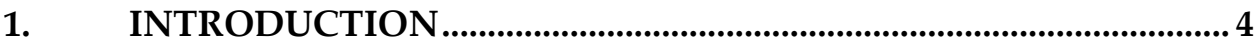

2. THE PRINCIPLE OF KAITIAKITANGA VERSUS THE PRINCIPLE OF “PROPERTY" ......................................................................................... 6

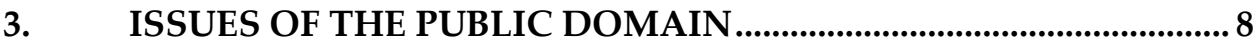

4. IP, TAONGA WORKS AND THEIR UNDERLYING MĀTAURANGA

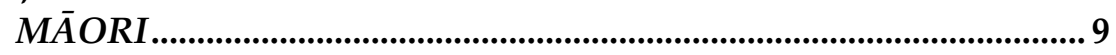

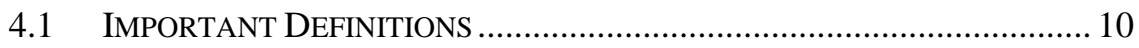

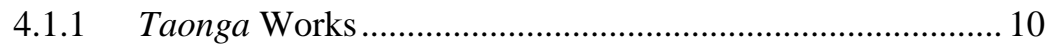

4.1.2 Taonga-Derived Works..................................................... 11

4.1.3 Mātauranga Māori ............................................................ 13

4.2 The Balance AgAinst Other InTERESTS...................................... 14

4.2.1 Offensive/Derogatory Public Use........................................ 14

(a) What is "offensive" or "derogatory"? ........................................... 15

(b) To whom must it be offensive? .................................................... 16

4.2.2 Non-Offensive Commercial Use ........................................ 17

4.2.3 Non-Commercial Public Use............................................. 18

4.2.4 Private Use ................................................................... 18

4.3 THE FRAMEWORK OF THE LEGAL MECHANISM AND GENERAL RECOMMENDATIONS ................................................................... 19

4.3.1 The Interface with Intellectual Property .............................. 19

4.3.2 Declaratory Rulings....................................................... 21

4.3.3 Creating Guidelines and a Register of Kaitiaki Interests ..... 22

4.3.4 Make-up of the Commission ............................................ 23

4.4 TRIPS AND OTHER INTERNATIONAL OBLIGATIONS........................... 23

4.4.1 Copyright.................................................................. 25

4.4.2 Industrial Design ........................................................ 27

4.4.3 Trade Marks .............................................................. 28

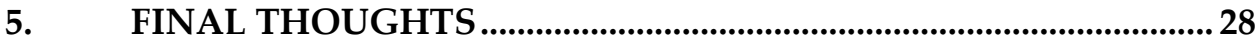

APPENDIX: SUMMARY OF THE TRIBUNAL'S RECOMMENDATIONS FOR TAONGA WORKS, TAONGA-DERIVED WORKS AND MĀTAURANGA MĀORI .............................................................. 31

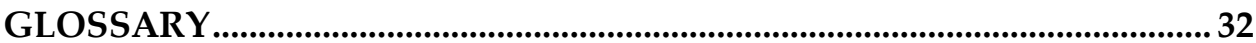




\section{INTRODUCTION}

Filed in 1991 by six iwi (tribes) ${ }^{1}$ on behalf of all tangata whenua (people of the land), ${ }^{2}$ the Wai 262 claim was one of the largest and most complex claims ever heard by the Waitangi Tribunal; a specialist court of inquiry, created to deal with issues relating to the Treaty of Waitangi, ${ }^{3}$ the founding Treaty between the indigenous people of New Zealand (the Māori) and the British Crown. It is often referred to as the Māori claim over fauna and flora, but it is far more encompassing than this. ${ }^{4}$ The Tribunal described it as being "about mātauranga Māori - the unique Māori way of viewing the world, incorporating both Māori culture and Māori traditional knowledge. It is no stretch to describe this claim as being about the survival of Māori culture and its ongoing place in this country." ${ }^{5}$ Mãtauranga Māori can also be described as "traditional knowledge" (TK) in its broadest sense, including within it all aspects of intangible indigenous cultural heritage $(\mathrm{ICH})$, whether technical or not. For example, the ideas underlying traditional cultural expressions (TCEs) are a part of mātauranga Māori. The report has the potential to affect the substance of future intellectual property rights (IPRs) in New Zealand. ${ }^{6}$ Being so broad and multifaceted, the Tribunal took twenty years to complete its report, 7 which was finally delivered to the New Zealand Government on 2 July 2011.

Wai 262 centres on Article 2 of the Treaty of Waitangi, the Māori version of which guarantees tino rangatiratanga (the unqualified exercise of chieftainship) over their lands, villages, and all their property and taonga (treasures). The concept of tino rangatiratanga is not en par with the Western concept of property, i.e. of exclusive ownership; rather, it is often considered to refer to autonomy, self-governance or authority, even selfdetermination, in the context of the Treaty. ${ }^{8}$ Taonga is wide in meaning and includes material and non-material heirlooms and sacred places, ancestral lore and genealogies (whakapapa). ${ }^{9}$ Thus, it also encompasses mātauranga Māori (and, thus, TK and TCE). ${ }^{10}$ The New Zealand Court of Appeal has confirmed that the right to tino rangatiratanga

$1 \quad$ Namely, Ngati Kuri, Ngati Wai, Te Rarawa, Ngati Porou, Ngati Kahungunu and Ngati Koata.

2 Peter Dengate-Thrush, 'Wai-262: New Zealand's Indigenous Flora and Fauna Claim' (1998) New Zealand Intellectual Property Journal, 1 (12), pp. 303-310, at p. 303. Tangata whenua is sometimes used by the Māori as a term to self-identify.

3 Treaty of Waitangi Act 1975 (NZ).

4 For a general overview of the claim, see New Zealand Ministry of Economic Development (NZ MED), 'Issues Related to Biodiversity' (8 December 2011), available at http://www.med.govt.nz/sectors-industries/naturalresources/biodiscovery/issues-related-to-biodiscovery (all online sources were accessed 25 January 2012).

5 Report of the Waitangi Tribunal on Claims Concerning New Zealand Law and Policy Concerning New Zealand Law and Policy Affecting Māori Culture and Identity (2011) Wai 262, at p. 1 [hereinafter Wai 262].

6 Daphne Zografos, 'New Perspectives for the Protection of Traditional Cultural Expressions in New Zealand' (2005) International Review of Intellectual Property and Competition Law, 36 (8), pp. 928-952, at pp. 935 [hereinafter Zografos, 'New Perspectives for TCES in NZ']; and Daphne Zografos, Intellectual Property and Traditional Cultural Expressions, Cheltenham, UK: Edward Elgar, 2010, at pp. 65-70.

7 The long length of time taken was also due to the great workload of the Tribunal and its limited funding; see Zografos, 'New Perspectives for TCES in NZ', supra note 6, at p. 935; and Maui Solomon, 'Intellectual Property Rights and Indigenous Peoples Rights and Obligations', Workshop on Instruments for Access and Benefit Sharing from Genetic Resources and Related Traditional Knowledge Issues, Global Biodiversity Forum 15, United Nations Environment Programme (Gigiri, Nairobi, Kenya, 12-14 May 2000), available at http://www.inmotionmagazine.com/ra01/ms2.html [hereinafter Solomon, 'IPRs and Indigenous Peoples Rights and Obligations'].

8 Toon van Meijl, 'Māori Intellectual Property Rights and the Formation of Ethnic Boundaries' (2009) International Journal of Cultural Property, 16, pp. 341-355, at p. 344.

9 Waitangi Tribunal, 'Treaty of Waitangi', available at http://www.waitangi-tribunal.govt.nz/treaty/; and Report of the Waitangi Tribunal on Te Roroa (1992) Wai 38, at p. 210 [hereinafter Wai 38].

$10 \quad$ Ibid., at p. 15. 
must be actively protected by the Crown. ${ }^{11}$ Therefore, the Crown has an active duty to ensure that Māori have self-governance over mātauranga Māori.

Under Wai 262, it was claimed that the Crown had failed to ensure Māori tino rangatiratanga due to the active dispossession of their lands, suppression of their culture and through neglect. ${ }^{12}$ Furthermore, it was claimed that Article 2 of the Treaty has not been fulfilled because the balance between the Western worldview and mätauranga Māori, guaranteed therein, clearly favours the former, such that mätauranga Māori has been "marginalised to a point where its very survival is threatened." 13 Finally, the Crown has failed in its obligation through allowing third parties to own, control and use taonga or mätauranga Māori, even when they have no traditional claim to them. ${ }^{14}$

The Wai 262 report centralises the principle of partnership inherent in the Treaty and the idea of balancing the promises and rights endowed upon both parties. Moreover, it recognises that it is necessary to protect Māori culture and identity in order to protect New Zealand culture and identity, ${ }^{15}$ stating that "[i]t is time for New Zealand law to reflect, and so for the world to learn, that these things belong to New Zealand and that they have kaitiaki [guardians]." 16 It is important to note that the role of the Tribunal is not to draft comprehensive legal solutions, but rather to provide directions to policymakers regarding the practical application of treaty principles and whether certain matters are inconsistent with those principles. ${ }^{17}$ Moreover, such a meticulous analysis would have been beyond what the claimants asked for, which was more general. ${ }^{18}$ This lack of detail is discussed throughout this paper and attempts are made to make suggestions to fill in the gaps.

The report itself differentiates between "taonga works" and "taonga species", and their respective mātauranga Māori, not because they are absolutely severable, but because there is a "natural division" between them. ${ }^{19}$ This discourse limits itself to addressing issues pertaining to taonga works, as taonga species are dealt with elsewhere. ${ }^{20}$ It starts by explaining the core concepts used in the report, before discussing the conclusions and recommendations of the Tribunal.

New Zealand Māori Council v Attorney-General [1987] 1 NZLR 687 (CA).

Wai 38, supra note 9, at p. 14 . See also Paul Myburgh, 'New Zealand / Aotearoa', in Toshiyuki Kono (ed.), The Impact of Uniform Laws on the Protection of Cultural Heritage and the Preservation of Cultural Heritage in the 21st Century, Leiden and Boston: Martinus Nijhoff Publishers, 2010, pp. 639-662, at p. 660; and Leo Watson and Maui Solomon, 'The Waitangi Tribunal and the Maori Claim to their Cultural and Intellectual Heritage Rights Property' (2000) Cultural Survival, $24 \quad$ (4), available online at http://www.culturalsurvival.org/ourpublications/csq/article/the-waitangi-tribunal-and-maori-claim-theircultural-and-intellectual-he.

13 Wai 38, supra note 9, at p. 14.

14 Ibid., at p. 15.

15 Ibid., at p. 98

16 Ibid., at p. 99

17 See Treaty of Waitangi Act 1975 (NZ), preamble.

18 Susy Frankel, 'A New Zealand Perspective on the Protection of Mātauranga Māori (Traditional Knowledge)', in Christoph B. Graber, Karolina Kuprecht and Jessica C. Lai (eds), International Trade in Indigenous Cultural Heritage: Legal and Policy Issues, Cheltenham, UK: Edward Elgar, 2012 (forthcoming) [hereinafter Frankel, 'A NZ Perspective'].

19 Wai 38, supra note 9, at p. 32.

20 Jessica C. Lai, 'Māori Traditional Knowledge and the Wai 262 Report: A Coherent Way Forward?', University of Lucerne, Switzerland, i-call Working Paper No. 03 (2012). 


\section{The Principle of Kaitiakitanga Versus the Principle OF "PROPERTY"}

A core principle of tikanga Māori (Māori customary law) is that of kaititiakitanga. ${ }^{21}$ This is Māori stewardship or guardianship over their people, lands, villages and taonga. It is an obligation that arises from their kin relationship, not only to people, but also to things that are believed to have a kin relationship according to Māori myths, legends and belief systems. It can, thus, encompass land, waters, plants, wildlife and cultural works; and also intangible things such as language, identity, culture and mātauranga Māori. The obligation includes the care of both the physical and spiritual, requiring the nurturing of mauri (the life force). Those that have the mana (authority, power or supernatural force) to carry the responsibilities are called kaitiaki, which may be an individual, whānau (family), hapū or izwi. The kaitiaki are not only responsible for the taonga works, species or the mātauranga Māori, they are also entitled to the benefits of the cultural and spiritual sustenance therefrom. This can include the economic benefits, if the commercialisation is in accordance with mātauranga Māori. ${ }^{22}$

It is often argued that IP is incapable of fully meeting the interests of indigenous peoples in their cultural heritage because of the vast difference between the principles of kaitiakitanga and "property". ${ }^{23}$ As stated by Māori academic Hine Lord:24

Derived from the careful and deliberate transmission of Māori traditional knowledge, or mātauranga Māori, is one's sense of identity and physical, mental and spiritual wellbeing ... To risk allowing this body of knowledge [mātauranga Māori] to be subjected to the forces of economic globalisation and intellectual property laws, devoid of any consideration of Māori cultural and spiritual values, would compromise the very essence of this knowledge base and, in the process, Māori rangatiratanga.

As such, "[t]he Wai 262 claim may be seen, at least in part, as a response to the tension between what are understood by Māori to be Article 2 rights and obligations, and the proprietary rights granted under intellectual property rights legislation". ${ }^{25}$ The Tribunal stated that the way forward is to "recognise that the guiding principles of kaitiakitanga on the one hand and property rights on the other are really different ways of thinking about the same issue - that is, the ways in which two cultures decide the rights and obligations of communities in their created works and valued resources." 26 After all, "IP law and tikanga Māori share a common interest in the growth of culture and identity." 27

The differences in the concepts are highlighted by the Treaty itself, the English version of which promises "full exclusive and undisturbed possession", compared to the Māori version, which protects tino rangatiratanga. In other words, property versus kaitiakitanga. In its Wai 262 report, the Tribunal found that considering mātauranga Implications for Environmental Risk Management', Environmental Risk Management Authority New Zealand 1998 Conference (New Zealand, 18 June 1998), available at http://archive.ermanz.govt.nz/newsevents/archives/events/erma-conf1998/maui-solomon.html.

24 Hine Lord, 'Tino Rangatiratanga and Trade Related Intellectual Property Rights' (1999) He Pukenga Kōrero, 4 (2), pp. 34-48, at p. 39.

25 NZ MED, Review of the Patents Act 1953: Boundaries to Patentability, Wellington, New Zealand: Regulatory and Competition Policy Branch, Ministry of Economic Development, 2002, at para. 88.

26 Wai 262, supra note 5 , at p. 33.

$27 \quad$ Ibid., at p. 46. 
Māori in terms of the English text did not make sense, because of the exclusive nature of the guarantee denoted therein. Though the exclusive rights are broad enough to guarantee IP-like rights in taonga, these were found to be too inflexible for mätauranga Māori and taonga works and the interests relating to taonga species, which cannot be held in such a way. The Tribunal stated:28

The language of exclusive rights is not apt for cultural knowledge or ideas - their boundaries
are too elusive and they are in a constant state of change. Exclusive possession of mātauranga
Māori in a modern context is impossible. Nor can any culture - Māori culture included - be
exclusively possessed. These things are not like land or other physical resources. Nor are they
like the fixed words and images of copyright and trade marks. They exist in the hearts and
minds of the communities that created them. In fact, even if it were possible to grant
exclusivity to a people's cultural and intellectual tradition so that only they could have access
to it, we think the act of doing so would be the death knell of that tradition. These things grow and
evolve at the margins, in response to external stimuli. We saw that kind of cultural growth
after Māori arrived in Aotearoa. And although British colonisation inflicted deep injuries on
Māori society, the introduction of literacy, iron tools, and Christianity generated a wave of
intellectual and artistic innovation that is still being felt today. Building a legal wall around
mātauranga Māori would choke it.

Of course, a taonga work can be exclusively owned, ${ }^{29}$ whether fixed or un-fixed. However, the differences between kaitiakitanga and ownership make this an uneasy marriage. The concerns of Māori over taonga works that have changed hands are often not over possession, but rather related to non-possessory rights, such as consultation as to the manner of display, copying, broadcast or other forms of commercial exploitation. ${ }^{30}$ In these cases, the guarantee endowed in the English version of the Treaty would be of little use, whereas that in the Māori version could be of service, as tino rangatiratanga better suits the concept of kaitiakitanga and is more fitting to the particular concerns of the Māori.

The Tribunal, thus, concluded that the question that it had to address was to what extent the guarantee of tino rangatiratanga should be used to offer a reasonable level of control to Māori over mātauranga Māori and taonga works. Towards this, the kaitiaki relationship is key and is ultimately what should be protected. The analysis requires a case-by-case three-stage assessment of: (1) understanding the relationship between the kaitiaki and the particular mātauranga Māori or taonga work; (2) identifying any other valid interests in the mätauranga Māori or taonga work; and (3) balancing the other interests against those of the kaitiaki. ${ }^{31}$ It was acknowledged that such an approach carries with it a level of uncertainty. However, it was considered important that there is the maximum amount of flexibility and the opportunity for "interest holders to explore ways in which all interests can be accommodated to the greatest extent possible", because "a system like this, rather than a system of generalised solutions, will limit conflict and increase cooperation." 32

Ibid., at p. 78 (emphasis added).

29 Ibid

$30 \quad$ Ibid., at p. 79.

31 Ibid., at p. 80. These three questions were set out for taonga works and their underlying mātauranga Māori, not for taonga species or the mātauranga Māori relating to biological resources. However, the analysis made by the Tribunal was nevertheless the same; see pp. 193-195.

32 Ibid., at p. 80. 


\section{Issues of THE PUblic Domain}

Often, in discussions regarding indigenous peoples rights over their cultural heritage, opponents cite the "public domain". In theory, once information enters the public domain, it cannot leave. Rather, it becomes a good of the commons, from which authors, creators and inventors can take and develop further works and inventions. ${ }^{33}$ Public domain theory is very much a construct of the Western world. Māori do not place such great value on free access and usage of knowledge. ${ }^{34}$ Rather, the concepts of tapu (to be sacred), mauri and whakapapa infer that access to information must be earned. ${ }^{35}$ Nevertheless, the Tribunal stated: ${ }^{36}$

If at some point in the past the possession of mātauranga Māori was exclusive and undisturbed, it is no longer possessed that way but is now shared. The only logical construction of this guarantee is that when exclusivity is lost, it can never be regained. Once mātauranga Māori is put into the public domain, it is not possible to retrieve it, for that would require a mechanism by which people could be made to "un-known" what they have learned.

The Tribunal further noted that this is also true for taonga works. This is particularly reflected in situations where a taonga work may have been sold or passed hands voluntarily.

Therefore, the Tribunal did not recommend amending the concept of the public domain, nor the way in which it is interpreted. In doing so, it implicitly rejected the creation of new IPRs. It has been argued by others that there needs to be recognition of the fact that there are many overlapping public domains. ${ }^{37}$ This would mean a reinterpretation of the public domain in assessing IPRs. However, the Tribunal did not discuss this, but rather accepted the Western public domain as the only one relevant for assessing classical IP interests. One could question the Tribunal's failure to seize the opportunity to acknowledge the different, but overlapping, spheres of the Māori and general New Zealand public domains. However, not having done so is consistent with finding that exclusive ownership and possession (which would be created through a second public domain) are an ill-fit for mätauranga Māori, taonga works and taonga species. Had the Tribunal sought to create two public domains, it would have contradicted its own finding that the important concept to be protected is that of kaitiakitanga. Moreover, even if a separate public domain was recognised for the Māori, this would not assist in the fact that much information lies in the overlap with the public domain of general New Zealand. Finally, accepting a single domain is far simpler logistically. Whether something is within a single public domain or not can be difficult to assess. Having to determine whether something is within two public domains, outside them, or within both could prove very challenging.

For a good discussion on the meaning of "public domain", see Brigitte Vézina, 'Are They In or Art They Out? Traditional Cultural Expressions and the Public Domain - Implications for Trade', in Christoph B. Graber, Karolina Kuprecht and Jessica C. Lai (eds), International Trade in Indigenous Cultural Heritage: Legal and Policy Issues, Cheltenham, UK: Edward Elgar, 2012 (forthcoming).

34 Wai 262, supra note 5, at p. 140.

35 Ibid. See also Moana Jackson, 'The Property of the Māori Intellect: A Review of The Politics of Māori Image and Design' (2003) He Pukenga Kōrero, 7 (1), pp. 32-33, at p. 32; and New Zealand, 'Detailed Thematic Report on Benefit Sharing', CBD (2000), at p. 2, available at http://www.cbd.int/doc/world/nz/nz-nr-abs-en.pdf.

36 Wai 262, supra note 5, at p. 79 (emphasis added). This statement was made regarding mātauranga Māori underlying taonga works, but the same finding was made for that relating to taonga species (at pp. 194-195).

37 This has been discussed in Brigitte Vézina, supra note 33. 
Finally and notably, though the Tribunal made unequivocal statements about the non-retroactivity of that which has made its way into the public domain, as will be discussed in this paper, it nevertheless found that what is in the public domain can still be protected to a degree. This is particularly with regard to the recommendations made relating to future commercial use of taonga works and mātauranga Māori, for which it was recommended that kaitiaki consultation and even consent might be necessary, regardless of whether the works or mätauranga Māori are in the public domain or not (see below, section 4.2.2). The Tribunal did not comment on the fact that this would bestow ownership-like rights of something in the public domain.

The approach taken by the Tribunal shares similarities with the "domaine public payant" (paying public domain) system, as found in the 1976 Tunis Model of Law on Copyright for Developing Countries or the 1977 Bangui Agreement, whereby works of folklore that are in the public domain "may be used without restriction, subject to the payment of a fee". ${ }^{38}$ Like the domaine public payant, the Tribunal's recommendation would not extract anything from the public domain, but allow for the protection of certain things within it, running somewhat contrary to the basic precept of the public domain that all inside it is free for use. However, the mechanism recommended by the Tribunal is far less intrusive on the public domain than the domaine public payant. This is because the Tribunal's recommendation is specifically tied and limited to the kaitiaki relationship. Thus, unlike the domaine public payant, there would be no need for the development of collecting societies or complex methods of distribution. Moreover, the recommendation directly addresses the issue that indigenous peoples are often more interested in control and the ability to maintain their stewardship, rather than remuneration.

\section{IP, TAONGA WORKS AND THEIR UNDERLYING MĀTAURANGA MÁTORI}

Taonga works are works in the copyright sense (such as stories, songs, sculptures and other art works) that have a katiaki. They may or may not be fixed. For the purposes of this section (section 4), mātauranga Māori refers to the underlying ideas and knowledge of taonga works. The claimants want to retain a level of control over taonga works that would allow them to maintain their kaitiaki obligations. ${ }^{39}$ They do not want to hide away their taonga works and mätauranga Māori from all others, but rather want recognised the ongoing relationship that they have with these, even after disclosed and in the "public domain".

On the other side, the Crown argued that what the claimants sought was impossible; once something is in the public domain, it cannot be taken out and have IP-rights imposed upon it. ${ }^{40}$ Doing so would impact on the interests of third parties who wish to use what is in the public domain and would be contrary to freedom of expression. Furthermore, it would affect the balance that has been created between bestowing rights to encourage creation/innovation and the public use of the products. Having a

38 Tunis Model of Law on Copyright for Developing Countries (1976), s. 17; and Bangui Agreement (1977), Article 59. See also WIPO, Intergovernmental Committee on Intellectual Property and Genetic Resources, Traditional Knowledge and Folklore, Secretariat, 'Note on the Meanings of the Term "Public Domain" in the Intellectual Property System with Special Reference to the Protection of Traditional Knowledge and Traditional Cultural Expressions/Expressions of Folklore', (WIPO Doc. WIPO/GRTKF/IC/17/INF/8, 2010), annex, at paras 55-58.

39 Wai 262, supra note 5, at pp. 65-71.

$40 \quad$ Ibid., at pp. 71-74. 
dynamic public domain is also important for further creation/innovation and ultimately economic development.

Interested parties stated their concerns of being restricted from using Māori symbols and designs and mātauranga Māori, particularly noting the importance of these in forming, representing and selling the New Zealand identity. ${ }^{41}$ They argued that it is important that artists and designers be able to use Māori symbols and designs to develop New Zealand's bicultural identity and to enrich and evolve both cultures through the creative flow of ideas. Concerns with locking images to particular groups of people and expecting conformity were also identified. Moreover, it was noted that the exact bounds of what is or is not appropriation is difficult to classify. It was suggested that what would be helpful would be creating a means by which artists and designers could know who to consult, because most people wanted to be respectful to the Māori. The creation of practical guidelines was also offered as an option. In summary, they confirmed the importance of being respectful, but did not want to be constrained by stronger IPRs. Rather, clear and accessible guidelines were proposed as a practical solution.

In its report, the Tribunal split its analysis and recommendations of intellectual property in taonga works into three categories: taonga works, taonga-derived works and mātauranga Māori. The following discusses the recommendations made for the three individually, before addressing the suggestions made in the report for the overall framework to implement these.

\subsection{IMPORTANT DEFINITIONS}

\subsubsection{Taonga Works}

Taonga work was defined as: (1) a creation from a pre-existing and distinctive body of knowledge, values and insights of mātauranga Māori (they are products of mātauranga Māori); and (2) a result of the effort and creativity of actual people whether in modern times or the distant past. ${ }^{42}$ Each taonga work has kōrero (it tells a story) and has a living kaitiaki. Furthermore, taonga works have whakapapa because they bring ancestors to life, often by representing or invoking an ancestor, or telling a story about one. Thus, taonga works also have mauri. Many taonga works are old, but they need not be and can be newly created. The Tribunal recommended the following working definition:43

\footnotetext{
A taonga work is a work, whether or not it has been fixed, that is in its entirety an expression of mātauranga Māori; it will relate to or invoke ancestral connections, and contain or reflect traditional narratives or stories. A taonga work will possess mauri and have living kaitiaki in accordance with tikanga Māori.
}

The Tribunal recommended that a framework should be established that allows kaitiaki to prevent offensive or derogatory public use of taonga works and their associated mätauranga. "By this we mean kaitiaki should be empowered to prevent uses of taonga works and their associated mātauranga Māori where they can establish that such uses are inconsistent with the integrity or mauri of either the work or mātauranga." 44 The Tribunal offered offensive uses of the $k a$ mate haka in

$42 \quad$ Ibid., at p. 44

$43 \quad$ Ibid., at p. 96.

$44 \quad$ Ibid., at p. 84 
advertisements as an example of something that should be able to be prevented through the established mechanism. ${ }^{45}$

Furthermore, because of the special kaitiaki relationship, the Treaty demands more than mere defensive rights for taonga works. Kaitiaki should be able to care for that relationship and derive benefits from it for the entire life of the work. This includes rights to consultation and, sometimes, to give consent for commercial use of taonga works. ${ }^{46}$

\subsubsection{Taonga-Derived Works}

Taonga-derived works or "hybrids" were defined as works that have a "distinctly Māori flavour, but ... incorporate elements from western and other cultural traditions." ${ }^{47}$ The Māori element in these is generalised or adapted and, thus, the connection to mätauranga Māori is questionable, or weak at best. ${ }^{48}$ Unlike with taonga works, there is no connection with whakapapa, no korrero and no kaitiaki. ${ }^{49}$ The Air New Zealand koru was given as an example of such a taonga-derived work. ${ }^{50}$ The following working definition was recommended: ${ }^{51}$

A taonga-derived work is a work that derives its inspiration from mātauranga Māori or a taonga work, but does not relate to or invoke ancestral connections, nor contain or reflect traditional narratives or stories, in any direct way. A taonga-derived work is identifiably Māori in nature or contains identifiably Māori elements, but has neither mauri nor living kaitiaki in accordance with tikanga Māori

It was recommended that the rights and protections for taonga-derived works be less than that for taonga works, because of the absence of a kaitiaki relationship. However, the inclusion of the Māori elements justifies a mechanism that allows for the prevention of offensive or derogatory public use. ${ }^{52}$

An important issue that was not fully resolved by the Tribunal springs from fact that the difference between a taonga work and a taonga-derived work would not always be clear. The Tribunal did deem that which category a work falls into should be decided by an appropriately composed body of experts, ${ }^{53}$ on a case-by-case basis. ${ }^{54}$ However, no additional guidance was given as to how exactly the body of experts was

45 Issues relating to the haka have been discussed elsewhere, see Jessica C. Lai, 'Māori Culture in the Modern World: Its Creation, Appropriation and Trade', University of Luzern, Switzerland, i-call Working Paper No. 02 (2010), at pp. 32-34 and 38-39. See also Susy Frankel and Megan Richardson, 'Cultural Property and "the Public Domain": Case Studies from New Zealand and Australia', in Christoph Antons (ed.), Traditional Knowledge, Traditional Cultural Expressions and Intellectual Property Law in the Asia-Pacific Region, Austin, Boston, Chicago, New York and the Netherlands: Wolters Kluwer, 2009, pp. 275-292, at pp. 280-283.

46 Wai 262, supra note 5, at p. 84.

$47 \quad$ Ibid., at p. 44.

48 Ibid., at p. 84

$49 \quad$ Ibid., at pp. 84-85.

50 Ibid., at p. 44. The Air New Zealand koru has been discussed elsewhere, Lai, supra note 45, at pp. 36-37. See also Frankel and Megan Richardson, supra note 45, at pp. 283-287.

51 Wai 262, supra note 5, at p. 96.

52 Ibid., at p. 85. A similar recommendation was made by the Māori Trade Marks Focus Group, in 2004. This Focus Group made a suggestion that there could be a differentiation between words, symbols, sounds or smells that are important to a specific Māori group (for which evidence of permission to use would be required) and those that are important to all Māori (for which registration would be dependent on whether it were "culturally appropriate"). ${ }^{22}$ See Māori Trade Marks Focus Group, Māori and Trade Marks. A Discussion Paper, Wellington, New Zealand: Ministry of Commerce, 1997, at p. 20.

53 This body of experts and its exact function are discussed further below. See section 4.3.

$54 \quad$ Wai 262, supra note 5, at p. 96. 
to make the decision. It would seem to the author here that the distinction cannot be made objectively and that the line between the two seems conceptually porous. As has been stated elsewhere, ${ }^{55}$ the opinion of Māori is by no means lacking in diversity, making it difficult to objectively and consistently answer the question of how much Western or "modern" material must make up a work for it to no longer be considered a taonga work but a taonga-derived work. Considering that Māori culture should be viewed as dynamic and constantly developing, how does one differentiate between this acceptable development (which may involve incorporating in aspects not of traditional Māori culture) and hybrids that cross the line and become taonga-derived works? This further begs the question of whether the racial descent of the creator is important towards this end. In other words, is one more willing to consider something a taonga work, rather than a taonga-derived work, if its creator is Māori in descent? If so, is that a justifiable distinction to make? Notably, this would not go both ways, as non-Māori can only make taonga-derived works, due to the requirement of a kaitiaki relationship.

The distinction between a taonga work and a taonga-derived work additionally alludes to the notion of "authenticity"; that a taonga work is "authentic", but a taongaderived work is not. This concept in relation to indigenous TCEs and TK has been often criticised ${ }^{56}$ and has even been considered to be a construct of colonisation. ${ }^{57}$ As Māori art historian Rangihiroa Panoho has noted, the selective focus on "classic" forms of "Māori art" (normally taken to be that which was practised at the time of discovery or first contact) ${ }^{58}$ is a reflection of Western culture and "Pākehā romantism", 59 as is the idea of "highlighting a glorious past and attempting to recreate it in the present." 60 In the attempted distinction is embedded an emphasis on difference and possibly idealised forms, which "silenc[es] ... the contemporary dimension of [Māori] culture." 61 Panaho concluded that "[r]ather than struggling with the obvious differences in visual language (compared to more traditional forms), we might think of ideas simply taking on different forms ... We are living in a world where all things may find redefinition and where even death involves life." 62

The author here is not necessarily disagreeing with the Tribunal's recommendations to differentiate between taonga work and taonga-derived work and to treat them differently; in fact, it makes logical sense from the perspective of the kaitiaki interest and, thus, the Treaty of Waitangi. Rather the author is trying to point out the difficulties in articulating and constructing the framework with which to do so, without simultaneously creating an "authentic"|"non-authentic" divide. There will be some situations where a work is clearly a taonga work or taonga-derived work. The

55 See Lai, supra note 45 , at pp. 36-37.

56 For example, with regard to the Australian Authenticity Certification Label Scheme, as discussed in Christoph B. Graber and Jessica C. Lai, 'Indigenous Cultural Heritage and Fair Trade - Voluntary Certification Standards in the Light of WIPO and WTO Law and Policymaking' (2011) Prometheus, 29, pp. 287-308. See also Leanne Wiseman, 'The Protection of Indigenous Art and Culture in Australia: The Labels of Authenticity' (2001) European Intellectual Property Review, 23 (1), pp. 14-25, at p. 14; Matthew Rimmer, 'Australian Icons: Authenticity and Identity Politics' (2004) Indigenous Law Journal, 3, pp. 139-179, at pp. 157-160; Jane Anderson, 'The Production of Indigenous Knowledge in Intellectual Property', University of New South Wales, Doctoral Thesis (2003), at pp. 240-241; and Terri Janke, Minding Culture: Case Studies on Intellectual Property and Traditional Cultural Expressions, Geneva: WIPO, 2003, at p. 147.

57 Rangihiroa Panoho, 'A Search for Authenticity: Towards a Definition and Strategies for Cultural Survival' (1996) He Pukenga Kōrero, 2 (1), pp. 20-25, especially at p. 23.

$58 \quad$ Ibid., at p. 23.

59 Ibid., at p. 24.

$60 \quad$ Ibid., at p. 22.

61 Ibid., at pp. 23-24.

62 Ibid., at p. 25 
complexity lies in capturing in words exactly why this is and, in doing so, creating some generally applicable guidelines. This is conceivably not a simple task for the body of experts. Nevertheless, it seems vital that this be done, to create some objective quality to the process.

\subsubsection{Mātauranga Māori}

The mātauranga Māori the claimants sought to protect was the information, ideas and intangible concepts underlying taonga and taonga-derived works. The Tribunal declined to define protectable mâtauranga Māori, stating it is as being as difficult to define as "Western knowledge". However, it noted that "it is the proximity of the mātauranga and the community that is the core defining factor, not the broad category of mātauranga Māori itself." 63 There exists generalised mātauranga Māori that is significant to all Māori and has no particular kaitiaki. There is also "closely held" mātauranga Māori that is specific to particular communities (such as a particular iwi or hapu) and does have kaitiaki.

Whether there is a living kaitiaki or not, the Tribunal found that mätauranga Māori cannot be wholly exclusively possessed because much of it is in the public domain, regardless of whether this was consensual or not. The Tribunal stated that "[i]t would be idle to suggest it can be 'un-known'" ${ }^{64}$ Of course that which is not in the public domain may be kept so. Nevertheless, it was concluded that all mātauranga Māori should also be afforded protection from offensive or derogatory public use. Furthermore, if a kaitiaki can be identified, he/she should have rights to be involved in consultation and decisions over the use of the mätauranga in commercial endeavours. ${ }^{65}$

It is worth questioning what "closely held" means. This term was used repeatedly by the Tribunal to differentiate between types of mātauranga Māori that warrant stronger rights than those that do not. However, the Tribunal failed to define its meaning. The only guidance given was that it is "community based", "attaches to particular iwi and hapu", and is "intimate in its nature". ${ }^{66}$ As with the distinction between taonga works and taonga-derived works, the difference between generalised and closely-held mätauranga Māori is not easy to articulate. From whose perspective would the mātauranga Māori be considered to be closely held? Arguably, given the stronger rights recommended for "closely held" mätauranga Māori, the standard of what is "closely held" would have to be objectively measurable.

It is not clear if there can be mātauranga Māori that has become generalised, but still has a kaitiaki who considers it closely held in the spiritual sense. For instance, when the mātauranga Māori becomes generalised across Māori through appropriation. If this situation is possible and, if so, what the Tribunal anticipated for such was not discussed. When there is a kaitiaki who has a strong relationship with the mätauranga Māori, but the mātauranga Māori has been used by other Māori commercially, this is not different from when non-Māori use it commercially. To be consistent, the kaitiaki should be restricted from doing anything about pre-existing use, but should be able to object to future use. This particular type of situation is difficult because it points to the issue that even Māori can misuse Māori culture. A large lacuna in the Wai 262 report is its failure to address

\footnotetext{
Wai 262, supra note 5, at p. 96 .

Ibid., at p. 85 .

Ibid., at p. 86.

Ibid., at p. 85. It was, thus, stated to include "local whakapapa; kōrero about historical and prehistoric ancestors and events; mōteatea [song poetry]; local kōrero about the environment, flora, and fauna; and so on."
} 
this, dealing only with the rights of Māori against non-Māori third parties. For example, it deals with competing kaitiaki interests (as discussed further below), but only so far as necessary to locate the correct kaitiaki to address non-Māori third-party use. The report is written under the presumption that Māori cannot misuse Māori culture. This is understandable, seeing as it addresses Treaty issues, which are inherently between the Māori and the Crown, such that inter-Māori issues are not primary. However, it leaves the analysis and recommendations incomplete.

One could also imagine cases where there is still a kaitiaki, but the mātauranga Māori is no longer "closely held" according to the guidance given by the Tribunal for the term's meaning. For instance, perhaps the kaitiaki views that it is better for the survival of the mätauranga Māori to be generalised across all Māori. Presumably, this would not receive the greater right proposed by the Tribunal. However, the kaitiaki may want to prevent non-Māori use. It is the katiaki's role to ensure the survival of the mātauranga Māori, such that he or she may be willing to extend use to all Māori, but not to nonMāori. As Article 2 of the Treaty protects the katiaki relationship, arguably, the kaitiaki in these situations should have a right to challenge future commercial use that they have not consented to. On the other hand, if the generalisation has occurred through a lack of care by the kaitiaki, there should be no right to object to future commercial use. Firstly, because they are to blame that the mātauranga Māori has become widespread. Secondly, because the former lack of attentiveness would indicate that the sudden attempt to enforce the kaitiaki relationship is rather convenient.

\subsection{THE BALANCE AGAINST OTHER INTERESTS}

Balancing the interests of protecting TCEs (and TK) against the expectations of those who wish to use them is an important principle and is, indeed, how the contours of IPRs have been defined. ${ }^{67}$ In questioning how Māori interests should be balanced against the interests of others, the Tribunal characterised two categories of interests. The first is the public interest in free access to information and ideas and the encouragement of creativity. ${ }^{68}$ This category relates to the public domain and the interest in keeping this diverse and dynamic. The second category addresses the IPRs of third parties. ${ }^{69}$ In addressing the second category, the Tribunal assessed whether nonMāori should be able to incorporate taonga works or mātauranga Māori into their works and obtain IPRs for these. For example, books, photographs, trade marks, or films with taonga works incorporated into them.

\subsubsection{Offensive/Derogatory Public Use}

The Tribunal concluded that nobody, not even IP owners, should be able to use taonga works, taonga-derived works or mātauranga Māori in an offensive or derogatory manner, in public. Though not stipulated by the Tribunal, presumably this includes use by Mãori as well as non-Māori. It is also seemingly retroactive, though this is not explicitly stated. The importance that New Zealand (as a Western country) places on freedom of expression was noted, but this was considered to be outweighed by the interest of protecting social cohesion and community standards, for which there are

67 New Zealand, 'Written Comments on the List of Issues for the Protection of Traditional Knowledge and Traditional Cultural Expressions/Expressions of Folklore', (WIPO Doc WIPO/GRTKF/IC/10/7 Prov, 2007), annex 1, at p. 9 [hereinafter New Zealand, 'Written Comments'].

68 Wai 262 , supra note 5 , at pp. 86-87.

69 Ibid., at p. 87. 
already many laws that prohibit offensive or derogatory expression. ${ }^{70}$ For instance, laws covering censorship and voluntary codes in the broadcasting and advertisement industry. Thus, ${ }^{71}$

[t]he only intellectual leap required here is to accept that there are distinctive standards of appropriate treatment in respect of mātauranga Māori and taonga works that, since they are cultural symbols or reflect community standards, deserve just as much protection as the "mainstream" equivalent.

It was recommended that anyone (whether kaitiaki or not, or Māori or not) should be able to complain of offensive or derogatory public use of all three categories..$^{72}$ This is because it is in the general public interest to prevent such behaviour. ${ }^{73}$ Objections should be raised on a case-by-case basis, the result of which could be an enforceable order to desist in use.

The recommendation of the Tribunal is wider in scope than the mechanism currently in place under trade mark law in New Zealand, which allows for the rejection and revocation of offensive trade marks, as it would allow for the challenge of marks used in trade, for which registration is not sought. Currently, common law passing off and consumer protection law regulate unregistered trade marks, but there is nothing to prevent the use of marks in trade on the grounds that they are offensive to the Māori.

\section{(a) What is "offensive" or "derogatory"?}

It has been stated that it should be possible that such a mechanism be used to prevent the production and sale of some fake Māori trinkets and mass-produced souvenirs (particularly as taonga-derived works), in New Zealand; of course, the mechanism would have no effect on international production and markets. ${ }^{74}$ It is unclear how true this supposition is, as it is dependent on how high the threshold is to show whether something is offensive or derogatory. That "offensive" or "derogatory" are by no means easy, objective or static standards was not lost on the Tribunal, which noted that this should be determined by an appropriately constituted authority. Nevertheless, the Tribunal did not give any indication as to how the two terms should be interpreted. It is not even clear if "offensive" and "derogatory" have different meanings.

If one were to presume that they would have a similar meaning to "offensive" used in trade mark law for the purposes of denying registration, 75 it would have to be something beyond mere bad taste, but something that would cause outrage and so should be censured. ${ }^{76}$ Examples are when something is likely to undermine current religious, family or social values. ${ }^{77}$

The Tribunal did posit that the balance should generally favour protecting cultural integrity of taonga works, taonga-derived works and mātauranga Māori. ${ }^{78}$ But, rather

Ibid.

Ibid., at p. 88 .

Ibid., at p. 93.

Ibid., at p. 94.

As stated by Wellington patent attorney Lynell Tuffery Huria, cited in Michelle Duff, 'Artists Fight Flood of

Fake Māori Trinkets', The Dominion Post (5 August 2011), p. A3.

75 Trade Marks Act 2002 (NZ), s. 17(1)(c).

76 IPONZ Trade Marks Practice Guidelines (26 January 2010), chpt. 4.1. See also Zografos, ‘New Perspectives for TCES in NZ', supra note 6, at p. 944.

77 IPONZ Trade Marks Practice Guidelines (26 January 2010), chpt. 4.1.

78 Wai 262 , supra note 5 , at p. 88. 
contradictorily, it further noted that some things that may "challenge our sensitivities" may be necessary or acceptable as social commentary and so should not be so censored. It is not clear what the Tribunal meant by something that may "challenge our sensitivities", but it is presumably something less than offensive or derogatory. This reasoning is analogous to why some copyright systems have parody/satire as a permitted act. The Tribunal stated that " $[\mathrm{w}]$ hat is important is that Māori should have recourse to an appropriately qualified forum to seek redress if they have concerns. The finer judgement calls will need to be made by that forum." 79 Moreover, because most offensive or derogatory uses of taonga works, taonga-derived works and mätauranga Māori are not deliberate, but rather in ignorance of what would be deemed correct, such a forum would have an educational function. ${ }^{80}$

It is also worth considering whether use can be offensive purely because the user is not Māori or is not the kaitiaki, the latter of course excluding taonga-derived works. For example, if use is otherwise completely according to tikanga Māori and mätauranga Māori, can offence be found because the user does not have the requisite mana for such use? If so, this would make the scope of "offensive" potentially very wide and would endow a right very close to "ownership". Thus, ethnicity should not play a role in deciding on offensiveness and nor should whether or not the user is the kaitiaki. Because the mātauranga Māori is in the public domain, being non-Māori or non-kaitiaki should not be relevant to assessing offensiveness. Moreover, use being inappropriate, not because of offence, but because of the existence of the kaitiaki relationship was dealt with separately by the Tribunal (see below, section 4.2.2), indicating that not having the requisite mana cannot in and of itself be offensive.

\section{(b) To whom must it be offensive?}

Because taonga-derived works have no kaitiaki, it could be difficult to determine offensiveness or if something is derogatory, or to reach the threshold of "outrage". Moreover, the lack of kaitiaki also makes problematic identifying who exactly the use must be offensive to. Indeed, even when there is a kaitiaki, there is still a question of to whom must the use be offensive. For example, is it all Māori, the kaitiaki, or the whannau, hapu $\bar{u}$ or iwi to which the kaitiaki belongs? Indeed, if a non-Māori lodges a complaint, is the assessment made from his/her point of view? Though the Tribunal does not clarify the question of to whom it must be offensive, it is somewhat self-explanatory that it must be either an individual of Māori descent or Māori collective. Nevertheless, clarification would need to be made (such as in guidelines) about whether the analysis could be made from the perspective of particular iwi, hapu, whānau, or an individual. The Trade Marks Act stipulates that it must be offensive to "a significant section of the community, including Māori" 81 and IPONZ has released guidelines clarifying what "significant" means. ${ }^{82}$ However, the IPONZ guidelines do not specify how large a group of Māori would be sufficient, though it appears that the intention of the New Zealand legislature was that particular groups of Māori be considered as "significant", 83

Ibid., at p. 89.

Ibid.

Trade Marks Act 2002 (NZ), s. 17(1)(c).

IPONZ Trade Marks Practice Guidelines (26 January 2010), chpt. 4.1.

Owen Morgan, 'Protecting Indigenous Signs and Trade marks - The New Zealand Experience' (2004) Intellectual Property Quarterly, 1, pp. 58-84, at p. 73; and Delegation of New Zealand, 'Specific Legislation for the Legal Protection of Traditional Cultural Expressions - Experiences and Perspectives of New Zealand', in WIPO, Intergovernmental Committee on Intellectual Property and Genetic Resources, Traditional Knowledge and Folklore, Secretariat, 'Presentations on National and Regional Experiences with Specific Legislation for 
for example an iwi. As will be discussed further below (section 4.3.1), there is the possibility that the group deemed as offended may be incoherent with the mechanism existent in the Trade Marks Act 2002.

It would be beneficial that the internal guidelines developed for determining the offensiveness of taonga works, taonga-derived works and mätauranga Māori clarify: (1) that offensiveness can be considered from the perspective of all Māori, iwi, hapū, whānau or individuals (if the kaitiaki is an individual); (2) that this depends on the context of the situation at hand, reflecting where the kaitiaki interest in the aspect of Māori culture used lies, if there is a kaitiaki; and (3) regardless of whether the assessment is made at the level of all Māori, iwi or an individual, there must be some aspect of te ao Māori (the Māori worldview) or tikanga Māori that is being offended, against which offence can be objectively assessed and judged to be offensive; otherwise, the assessment would be heavily subjective. This approach would allow for flexibility, with the third requirement ensuring that a "significant" number of Māori would be offended.

\subsubsection{Non-Offensive Commercial Use}

As to non-offensive/derogatory public use of taonga works, taonga-derived works and mātauranga Māori, this would depend on the kaitiaki relationship. Thus, nonoffensive/derogatory use of taonga-derived works should not be limited in any way, as they have no kaitiaki and so no specific relationship to protect. ${ }^{84}$ The balance of interest then must favour third-party users. On the other side, non-offensive/derogatory use of taonga works should be afforded some limitations, due to the existence of kaitiaki relationships. ${ }^{85}$ If there are no pre-existing IPRs to counterbalance the interests of the kaitiaki, third parties should not be able to commercially exploit taonga works without consulting the relevant kaitiaki. In some situations, consent from kaitiaki may also be required. The same holds true for closely-held mātauranga Māori that has an identifiable kaitiaki. ${ }^{86}$ However, the Tribunal acknowledged that pre-existing uses of taonga works and mātauranga Māori should not be limited, as the uses were made in accordance with the existing legal framework and any new law or protection system should not be retroactive.

According to the Tribunal, only kaitiaki (with the relevant responsibility) should be able to raise complaint. Kaitiaki should be able to prevent commercial exploitation of taonga works or closely-held mätauranga Māori, unless there has been consultation for the use. In some cases, consent may even be necessary before further use can proceed. That requiring consultation or consent to use creates "ownership-like" rights over something in the public domain and has the analogies with domaine public payant systems has been discussed above (section 3). Whether consultation is enough or consent is required is a discretionary decision, which must be made by striking a balanced and considering, ${ }^{87}$

the nature of the proposed use: for example, consultation may well be sufficient for a relatively minor use such as a one-off public exhibition, whereas representing an important tribal taonga work on postcards or stamps would almost certainly require consent.

the Legal Protection of Traditional cultural Expressions (Expressions of Folklore)', (WIPO Doc. WIPO/GRTKF/IC/4/INF/2, 2002), annex II, at para. 47.

84 Wai 262 , supra note 5 , at p. 89.

85 Ibid.

86 Ibid.

87 Ibid., at p. 96 
The effect on the user will also be relevant. Where the proposed use has significant commercial implications for a user, [it may be better] to encourage consultation as a first step, in the hope that dialogue produces compromise. The very purpose of such consultation is that it provides an opportunity for early identification of competing interests and potentially for early dispute resolution.

This will allow for the possibility that kaitiaki may be open to commercialisation, so long as there is consultation and perhaps benefit-sharing. Ultimately, the choice between consultation and consent "is about balancing the impact on the kaitiaki against that on the user, and encouraging compromise where possible." 88

As with offensive use, it would be prudent that guidelines be developed, outlining in more details the criteria against which the discretion would be utilised. To retain flexibility, these could be listed non-exclusively, allowing for the consideration of other factors. Over time, with the growth and experience gained through a body of decisions, the criteria could be developed iteratively. As noted above, the Tribunal listed the number of uses and the effect on the user as two criteria. Others could be: the reach of the use (geographical or numerical), the level of sacredness of the taonga works or closely-held mātauranga Māori, the effect of the use on the kaitiaki relationship, or the type of commercial use.

\subsubsection{Non-Commercial Public Use}

The Tribunal also recommended that non-commercial public use should not be controlled in any way, as this would prevent use in schools, for example. ${ }^{89}$ The report was not clear as to whether there should be delineation between non-commercial public use that is offensive/derogatory and that which is not. Presumably, it meant to do so and non-commercial public use is only unchallengeable so long as it is not offensive/derogatory. Otherwise, practices such as the "haka party incident" 90 would be permitted and unchallengeable. Moreover, it is more consistent with the finding that all offensive or derogatory public use of taonga works, taonga-derived works or mätauranga Māori should not be allowed.

\subsubsection{Private Use}

In the report, the Tribunal demarcated private use from public commercial use and public non-commercial use. It recommended that private use of taonga works, taongaderived works or mätauranga Māori should not be challengeable. ${ }^{91}$ Two reasons were given for this finding. Firstly, it would be largely impossible to control private use. Secondly, it would be resented as an unjustifiable imposition on private life and

$88 \quad$ Ibid.

$89 \quad$ Ibid., at p. 89

90 This was a well-known situation in New Zealand, where engineering students at the University of Auckland (since 1954) had performed a mock version of the Ka Mate haka as part of their post-graduation celebrations. The versions differed, but were all disrespectful and lewd, including racial slurs against the Māori and sexually vulgar gestures. Furthermore, the performers were often drunk, dressed in grass skirts and painted with obscenities. See Paul D'Arcy, 'Book Review: Kayleen M. Hazelhurst, Racial Conflict and Resolution in New Zealand: The Haka Party Incident and Its Aftermath 1979-1980' (1990) The Contemporary Pacific, 2 (4), pp. 223-225; Stephen Pritchard, 'Between Justice and Law in Aotearoa New Zealand: Two Case Studies' (2000) Law and Critique, 11, pp. 267-286, at pp. 270-272; and Ranginui J. Walker, 'The Genesis of Māori Activism' (1984) The Journal of the Polynesian Society, 93 (3) pp. 267-282, at p. 278.

91 Wai 262, supra note 5 , at p. 89 
personal choice. Dealing with private use separately from public use is further justified because it acknowledges that many aspects of Māori culture have become part of the general New Zealand identity. ${ }^{92}$ Moreover, it is possible that New Zealand's international human rights obligations, particularly encapsulated in the right to privacy, would not allow for the limitation of private use of taonga works, taonga-derived works or mātauranga Māori (discussed further below, section 4.4.1). ${ }^{93}$

\subsection{THE FRAMEWORK OF THE LEGAL MECHANISM AND GENERAL RECOMMENDATIONS}

\subsubsection{The Interface with Intellectual Property}

The Tribunal pointed out the importance of creating a framework that interfaces with existing IP law. ${ }^{94}$ Of all the classical forms of IP, trade mark law (at least in New Zealand, Canada and the USA) has been the most receptive to indigenous interests over their TCEs. All three of the aforementioned states provide schemes, whether through legislation or otherwise, that utilise trade marks for the benefit of indigenous peoples. For example and as already mentioned, the New Zealand Trade Marks Act 2002 allows the Commissioner of Trade Marks to reject applications that are or are likely to be offensive to the Māori, with advise from the Māori Trade Marks Committee. ${ }^{95}$ The Tribunal stated that these "are worthwhile provisions that give some weight to the Māori perspective". ${ }^{96}$ The mechanism for objection was considered to be valuable and capable of protecting the kaitiaki interest. It is, thus, not surprising that the Tribunal recommended creating a commission (hereinafter "the commission") with an analogous function to the Māori Trade Marks Committee, with a role of dealing with complaints regarding the use of taonga works, taonga-derived works or mätauranga Māori. It noted that this was more a job for experts than for the general courts. ${ }^{97}$

The Tribunal specifically noted that the suggested framework would not create new IPRs or proprietary rights. ${ }^{98}$ It would be a sui generis system that operates outside of classical IP norms, via recognising the kaitiaki relationship. In other words, it would specifically relate to the Treaty obligation to protect tino rangatiratanga (rather than exclusive and undisturbed possession) over taonga. The proposed framework would create a statutory participatory right in making decisions over the commercial use of taonga works and closely-held mātauranga Māori. The right would be potentially perpetual, dependent on the kaitiaki relationship.

The requirement that the new framework interface with existing IP systems means that the rights of future IPRs would be restricted by the findings of the commission. ${ }^{99}$

92 See Ministry of Culture and Heritage, 'Cultural Indicators for New Zealand', Cultural Statistics Programme (2009), at p. 41; Statistics New Zealand, Culture and Identity Statistics Domain Plan: Draft for Consultation, Wellington: Statistics New Zealand, 2009, at p. 31 (this Draft also discusses how there is currently insufficient data on the impact on Māori culture on non-Māori New Zealanders (at pp. 27 and 32)).

93 UN, International Covenant on Civil and Political Rights (CCPR), 999 UNTS 171 and 1057 UNTS 407; 6 ILM 368 (adopted on 16 December 1966, entered into force 23 March 1976), Article 17. For a discussion on what "privacy" is, see Sarah Joseph, Jenny Schultz and Melissa Castan, The International Covenant on Civil and Political Rights, Oxford: Oxford University Press, 2000, paras 16.01-16.02. Wai 262, supra note 5 , at p. 92 .

Trade Marks Act 2002, ss 17(1)(c) and 178. This has been discussed in Lai, supra note 45, at pp. 21-22.

96 Wai 262, supra note 5, at p. 64.

$97 \quad$ Ibid., at p. 93.

98 Ibid., at p. 92.

99 For a discussion on the importance of an interface with IP law, see Frankel, 'A NZ Perspective', supra note 18. 
For example, if $\mathrm{X}$ takes a photograph of an existing taonga work, such as a publically displayed sculpture, ${ }^{100}$ he/she may have copyright in his/her photograph, but his/her right to use it commercially could be limited by rights of consultation and possibly consent of the kaitiaki. Copyright is not registered, but simply exists or does not. It follows that copyright cannot be removed. If the commission were to find a work to be offensive and rule for the discontinuation of publication or other public use, this would not be contrary to international obligations, as copyright does not confer the right to use, publish, etc., but to prevent third-parties from doing these acts (discussed further below, section 4.4.1).

The Tribunal further stated that this would also mean that no IPR should be registered contrary to a commission finding, and registration of internet domain names, trade marks or registered designs should be refused or removed if the commission were to find offensive or derogatory use, or that a kaitiaki relationship means that there should be consultation or possibly the obtainment of consent. ${ }^{101}$ Therefore, the commission should take over the functions of the existing Māori Trade Marks Committee. ${ }^{102}$ The report also stated that the commission's findings should be binding on the Commissioner of Trade Marks. ${ }^{103}$ Currently, the Māori Trade Marks Committee only makes recommendations to the Commissioner. ${ }^{104}$ The role of the Māori Trade Marks Committee is only advisory because the Commissioner has a broader role than merely assessing offence to Māori, also addressing the offence in light of the registration and use and any other relevant factors. Making the role of the commission binding would limit the Commissioner's ability to assess and balance other issues and interests.

Furthermore, the recommendation could create a potential problem because the Trade Marks Act 2002 requires that a mark must be offensive to a "significant section of society", which may not be coherent with what the commission deems as appropriate to be the offended party (discussed above, section 4.2.1(b)). Potentially, the commission could consider a smaller group of people as capable of being offended under the Tribunals' recommended mechanisms than under the Trade Marks Act, such as an individual kaitiaki or whānau, forcing the Commissioner of Trade Marks to reject or revoke marks which would not be offensive to a "a significant section of the community". In order to avoid this inconsistency, "offensive" may have to be defined such as to ensure non-esoterism or misuse. As stated above, this could be by introducing an objective measure through requiring that there be some aspect of te ao Māori or tikanga Māori that is being breached (see section 4.2.1(b)).

When use of taonga works or mātauranga Māori is non-offensive, the report unequivocally states that kaitiaki should only be able to challenge future use of taonga works or mātauranga Māori (not taonga-derived works) and there should be no recourse if there are IPRs that were assigned before the enactment of the recommended mechanism. Laws are seldom retroactive; particularly if they have negative implications on whomever they are targeted at. This is for legal certainty. If a state's commercial law were retroactive, investors would be hesitant to make investments in that state. Comparatively, when use (of any of the three categories) is offensive, the Tribunal recommended that anyone can challenge it, despite any pre-existing IPRs. This is consistent with the current Trade Marks Act 2002, through which one can challenge

103

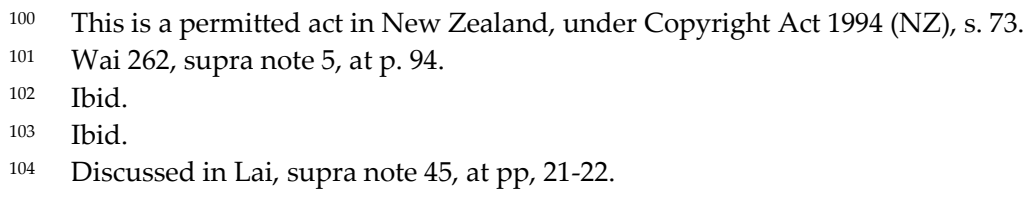


registrations that were made before the new provisions on "offensiveness" came into being, ${ }^{105}$ not just those made after. ${ }^{106}$ The Act allows the Commissioner or the courts to declare a registration invalid if a "culturally aggrieved" person so applies, to the extent that the trade mark was not registrable because it would be likely to offend, as deemed from the date of its registration. ${ }^{107}$ It would, thus, seem that limiting offensiveness outweighs the undesirability of the uncertainty of retroactivity.

\subsubsection{Declaratory Rulings}

Interestingly, the report further recommended that potential users of aspects of Māori culture should be able to apply to the commission for a declaratory ruling as to whether the proposed use would be offensive or not. ${ }^{108}$ This should be a quick, informal and inexpensive process. ${ }^{109}$ This is good because it would allow an early detection of any possible offensive/derogatory use and alert the potential user to any existing kaitiaki interests, which could lead to consultation and agreement, before there is a chance for a dispute to arise. However, if the process needs to be quick, informal and inexpensive, one wonders how thorough it would be. For instance, would (and indeed could) all kaitiaki interests be identified in the short analysis? If not, potential users could move forward with their projects, thinking that they are safe from future accusations of offensive use or breach of Māori interests, when this might not be the case and they could later be ordered to desist use.

It would be difficult for the commission to balance between the interests of speed and low costs, on the one hand, and thoroughness and certainty, on the other. To an extent, parties are likely to be willing to pay more to have greater legal certainty. Users who obtain a declaratory ruling in their favour, only to later have a claim lain against them are likely to resent the process and would be less willing to use it in future. Moreover, they would tell their friends and business colleagues of their experiences. Thus, for this function to work, it would be necessary that the commission get the aforementioned balance correct and also to define exactly what having a declaratory ruling means.

In doing so, it would be worth considering if the rights held by having a declaratory ruling should be different for use in taonga-derived works than use of taonga works or mātauranga Māori. Because the aspects of Māori culture in taonga-derived works would by definition be general and there would be no kaitiaki, it might be beneficial to make declaratory rulings for such binding. The chances of getting such a decision incorrect are low, as would be the associated harm. On the other hand, with taonga works or mātauranga Māori, the presence of kaitiaki can mean that there is someone who can clearly challenge the commission's declaratory rulings. Furthermore, the harm to the kaitiaki relationship could be high. This means that these rulings should only be evidence of good faith and may play in favour of their holders in later decisions or

Sections 177-180 (establishing the Māori Trade Marks Committee), 199 and 200 came into force on 5 December 2002, and the rest of the Act on 20 August 2003; see Trade Marks Act 2002, s. 2.

106 Academics appear to be unsure of whether this is so. Daphne Zografos states that there is no retroactivity; Zografos, 'New Perspectives for TCES in NZ', supra note 6, at p. 945. However, there is also academic opinion that the use of section 73(1) can be retroactive; Earl Gray, 'Māori Culture and Trade Mark Law in New Zealand', in Christopher Heath and Anselm Kamperman Sanders (eds), New Frontiers of Intellectual Property. IP and Cultural Heritage - Geographical Indicators - Enforcement - Overprotection, Oxford and Portland, Oregon: Hart Publishing, 2005, pp. 71-96, at p. 87; and Morgan, supra note 83, at pp. 75-76.

107 Trade Marks Act 2002, s. 73. See also New Zealand, 'Written Comments', supra note 67, annex 1, at p. 13.

108 Wai 262, supra note 5, at p. 93.

109 Ibid. 
discussions, such as on any damages, costs or benefit-sharing, to create an incentive to obtain a non-binding declaration.

\subsubsection{Creating Guidelines and a Register of Kaitiaki Interests}

The Wai 262 report proposed that the commission establish best-practice guidelines for potential users of aspects of Māori culture. ${ }^{110}$ The commission would become the first port of call for those wishing to use Māori culture in an appropriate manner. Such guidelines would be similar to those that have been developed by the Māori Trade Marks Advisory Committee, but would play more of an external role. Such guidelines would be useful for the many potential users who do not wish to cause offence to the Māori and who wish to respect their kaitiaki role. ${ }^{111}$ They would also serve an educational function. As was stated by the Māori Trade Marks Focus Group, "there is a need for Māori to assist in the protection and appropriate use of Māori words, symbols, sounds or smells". ${ }^{112}$ Moreover, they "should develop codes of ethics to be observed by 'external users' (for example, other hapū and iwi, as well as governmental an nongovernmental agencies." ${ }^{113}$ Unlike the Wai 262 report, the Māori Trade Marks Focus Group alluded to the fact that Māori can also appropriate culture within themselves, for example, between hapu and iwi. If any legislation created as a response to the Wai 262 report does not deal with this reality, the author here recommends that iwi and hapu (as appropriate) develop guidelines with this in mind and not only thinking about nonMāori appropriation.

The report additionally recommended that the commission operate a register of kaitiaki and the particular taonga works or closely-held mātauranga Māori that they have an interest in. ${ }^{114}$ Such registration would make it easier for potential users to identify an existing interest that they should take into account and would also add credibility to one's claim of having a kaitiaki interest. ${ }^{115}$ However, the Tribunal stated explicitly that registration should not be compulsory and whether or not an interest has been registered should not affect one's standing to object to offensive or derogatory use. ${ }^{116} \mathrm{~A}$ public notification system was recommended, whereby the commission could hear and resolve objections to the registration. If there are no objections, the interest can be registered. Alternatively, the registration could only depend on completely formal requirements and status as a kaitiaki could be challenged and determined at a later stage, if there is ever a dispute relating to the relevant taonga works or closely-held mätauranga Māori raised to the commission. ${ }^{117}$

$110 \quad$ Ibid., at p. 95

111 As, Maui Solomon has noted, most companies use Māori names and designs without being aware that they have caused offence; Maui Solomon (for the NZ MED), 'Peer Review Report on WIPO Documents: "The Protection of Traditional Cultural Expressions/Expression of Folklore: Revised Objectives and Principles" (WIPO/GRTKF/IC/8/4); and "The Protection of Traditional Knowledge: Revised Objectives and Principles (WIPO/GRTKF/IC/8/5)"' (2005), at para. 5.8, appendix to: WIPO, Intergovernmental Committee on Intellectual Property and Genetic Resources, Traditional Knowledge and Folklore, Secretariat, 'The Protection of Traditional Cultural Expressions/Expression of Folklore: Table of Written Comments on Revised Objectives and Principles', Eleventh Session (WIPO Doc. WIPO/GRTKF/IC/11/4(b), 2007).

112 Māori Trade Marks Focus Group, supra note 52, at p. 10, regarding registered trade marks.

113 Ibid., at p. 12.

114 Wai 262, supra note 5, at p. 95

115 Ibid.

116 Ibid.

117 Ibid. 


\subsubsection{Make-up of the Commission}

Finally, it was noted that the make up of the commission (and its secretariat) would have to be multidisciplinary, with experts in mätauranga Māori, IP law, commerce, science and stewardship of taonga works and documents. ${ }^{118}$ The author here agrees with all of these points, but would add that the formation of the commission must be done through a process reflecting Māori self-determination. This is required by the UN Declaration on the Rights of Indigenous Peoples (UNDRIP), which states that "[i]ndigenous peoples have the right to participate in decision-making in matters which would affect their rights, through representatives chosen by themselves in accordance with their own procedures, as well as to maintain and develop their own indigenous decision-making institutions." 119 The tendency in legislation so far (such as in the Trade Marks Act) has been to allow the governmental Minister in charge to select the Māori representatives. This trend should be broken and a procedure should be created instead with consultation with iwi about how the Māori can select their own representatives. After all, it is they who best know who their leaders are in any given field. As stated by Māori academic Moana Jackson, "if art and philosophy are the self expression of a collective intellectual tradition then their safest protection will only lie in political and constitutional processes that have been self-determined by our people." ${ }^{120}$

\subsection{TRIPS AND OTHER INTERNATIONAL OBLIGATIONS}

The Agreement on Trade-Related Aspects of Intellectual Property Rights (TRIPS) ${ }^{121}$ was concluded during the Uruguay Round of the General Agreement on Tariffs and Trade (GATT), through which the World Trade Organization (WTO) was also formed. TRIPS is considered to be the most important international agreement on IP, incorporating into it much substantive law from previous international agrements, such as the Berne Convention and Paris Convention, ${ }^{122}$ and bringing them within the realm of the WTO dispute settlement process. New Zealand was a member of the GATT prior to the formation of the WTO and so partook in the negotiations. However, the Māori have complained that consultation during this process was inadequate. ${ }^{123}$ Because

118 Ibid., at p. 96

119 UN, Declaration on the Rights of Indigenous Peoples (UNDRIP), GA Res. 61/295 (UN Doc. A/61/L.67 and Add.1) (adopted on 13 September 2007), Article 18.

120 Jackson, supra note 35 , at p. 33.

121 WTO, Agreement on Trade Related Aspects of Intellectual Property Rights (TRIPS), Marrakesh Agreement Establishing the World Trade Organization, Annex 1C, 1869 UNTS 299; 33 ILM 1197 (adopted on 15 April 1994, entered into force 1 January 1995).

122 WIPO, Berne Convention for the Protection of Literary and Artistic Works (Berne Convention) (1886) (adopted on 9 September 1886), as revised at Paris (24 July 1971) and as amended on 28 September 1979; and WIPO, Paris Convention for the Protection of Industrial Property, 828 UNTS 303 (adopted on 20 March 1883, entered into force 16 April 1970), as revised at Stockholm (14 July 1967).

123 See, for example, Aroha Mead, 'Indigenous Rights to Land and Biological Resources. The Convention on Biological Diversity', Biodiversity: Impacts on Government Business and the Economy, International Institute for Research (NZ) Ltd and Department of Conservation (Auckland, New Zealand, 4-5 August 1994), at p. 9-10, collected in Aroha Mead, Nga Tikanga, Nga Taonga. Cultural and Intellectual Property : The Rights of Indigenous Peoples, Auckland, New Zealand: International Research Institute for Māori and Indigenous Education, 1994, pp. 4-15 [hereinafter Mead, 'Indigenous Rights to Land and Biological Resources']; and Aroha Mead, 'Delivering Good Services to the Public without Compromising the Cultural and Intellectual Property of Indigenous Peoples', The Public Service: Delivering Good Services to the Public, International Ombudsmen Institute and New Zealand Institute of Public Administration (Wellington, New Zealand, 8 October 1993), at p. 2, collected in Aroha Mead, Nga Tikanga, Nga Taonga. Cultural and Intellectual Property : The Rights of Indigenous 
TRIPS binds New Zealand to laws that could impact on their tino rangatiratanga in mātauranga Māori, taonga works and taonga species, the Māori believe that it was the Crown's duty under the Treaty to consult with them.124 Seeing as New Zealand was already a Contracting Party to both the Berne and Paris Conventions (and several other relevant international treaties) and already had relatively strong IP systems in place, the impact that the accession to TRIPS had on New Zealand law is debatable and was arguably minimal, particularly with respect to the subject matter of the Wai 262 claim. ${ }^{125}$

Nevertheless, in the Wai 262 claim, the concern was raised that TRIPS prevented the Crown from providing protection for the kaitiaki interest in mätauranga, taonga works and taonga species. However, as noted by the Tribunal (and conceded by the Crown), ${ }^{126}$ TRIPS consists of minimum standards. This means that New Zealand can, in theory, create stronger and/or additional sui generis rights other than those envisioned in TRIPS, including providing mechanisms to protect the kaitiaki interest in mātauranga Māori, taonga works and taonga species. There need only be the will to do so. ${ }^{127}$ Moreover, the government has previously indicated willingness to develop country- or region-specific approaches for the protection of traditional knowledge. ${ }^{128}$ However, though TRIPS only contains minimum standards as to the rights to and from protection, it also contains some ceilings with respect to the exceptions to those rights. For all three of the main areas of IP law (namely, trade mark, copyright and patent law), TRIPS outlines when a Member State can make an exception to the right to protection and the rights entailed thereby. ${ }^{129}$ Thus, any sui generis system that requires a limitation of the right to a patent, trade mark or to copyright, or the rights of such owners, must fall into one of the exceptions.

That the rights conferred by IP may be limited, and also the ability to grant those rights in the first place, is confirmed as a TRIPS Principle. It is recognised that Members may want to formulate their laws to "adopt measures necessary to protect public health and nutrition, and to promote the public interest in sectors of vital importance to their socio-economic and technological development". ${ }^{130}$ TRIPS further acknowledges as a Principle that Members may need measures to prevent "the abuse of intellectual property rights by right holders or the resort to practices which unreasonably restrain trade or adversely affect the international transfer of technology." 131

The following discusses whether the Tribunal-proposed sui generis mechanisms - so far as they impact on IPRs - are compliant with the explicit limitations on rights and exceptions to grant stipulated within TRIPS and other international agreements that New Zealand is obliged to comply with.

Peoples, Auckland, New Zealand: International Research Institute for Māori and Indigenous Education, 1994, pp. 24-33.

124 Solomon, 'IPRs and Indigenous Peoples Rights and Obligations', supra note 7; and Huhana Smith, 'A Comment on The Politics of Māori Image and Design' (2003) He Pukenga Kōrero, 7 (1), pp. 38-41, at p. 39. The impact of TRIPS and multilateral agreements on Māori TK and TCEs is discussed thoroughly in Lord, supra note 24 , at pp. $37-43$.

125 Dengate-Thrush, supra note 2, at pp. 306-307.

126 Wai 262, supra note 5, at pp. 50-51 and 72-74.

127 Ibid., at p. 74

128 NZ MED, Review of the Plant Variety Rights Act 1987. A Discussion Paper, Wellington, New Zealand: Ministry of Economic Development, 2002, at para. 105.

129 TRIPS Agreement, Articles 13 (copyright), 26.2 (trade marks), 27.2 and 27.3 (patents).

130 TRIPS Agreement, Article 8.1.

131 TRIPS Agreement, Article 8.2. 


\subsubsection{Copyright}

Copyright is not granted, but is automatically obtained without registration. ${ }^{132}$ Thus, even if found to be offensive, works that satisfy the test of originality (and other requirements) have copyright and this cannot be removed. As stated above, copyright does not endow positive rights. Rather, it offers exclusivity over certain acts in relation to a work by giving the copyright owner the right to permit or prevent others doing those certain acts. ${ }^{133}$ For example, copyright does not give the owner of a work the right to reproduce the work, but the right to prevent third parties from doing so. The requirements for limitations and exceptions to exclusive rights outlined in TRIPS 134 (and the Berne Convention, of which New Zealand is a signatory) ${ }^{135}$ are targeted at how Member States can allow for third parties to perform acts that would otherwise infringe copyright. ${ }^{136}$ Thus, copyright law is really about the restricted and permitted acts of third parties, ${ }^{137}$ and does not concern itself with limiting how a copyright owner can use his/her work per se.

Indeed, Article 17 of the Berne Convention (which is incorporated into the TRIPS Agreement $)^{138}$ stipulates that:

The provisions of this Convention cannot in any way affect the right of the Government of each country of the Union to permit, to control, or to prohibit, by legislation or regulation, the circulation, presentation, or exhibition of any work or production in regard to which the competent authority may find it necessary to exercise that right.

Government measures for the sake of ordre public that limit a copyright holder's freedom to exploit his/her work on the marketplace do not contravene the Berne Convention. ${ }^{139}$ This is why censorship laws preventing copyright owners from publishing, distributing or broadcasting certain (such as indecent) works do not infringe copyright or breach the Berne Convention or TRIPS agreement. Thus, the Tribunal-proposed mechanism would be Berne- and TRIPS-compliant.

For works with copyright, from the report it would seem that the commission could not order that the works or any copies thereof be destroyed on finding offensive use of a taonga work, taonga-derived work or mätauranga Māori. It would only be able to order a cessation of future public use. This would be consistent with the Tribunal's

132 This is required by Berne Convention, Article 5(2).

133 This is in civil law jurisdictions, as well as common law ones; see Felix Daum, 'Copyright, European Competition Law, and Free Movement of Goods and Services', in Michel M. Walter and Silke von Lewinski (eds), European Copyright Law. A Commentary, Oxford: Oxford University Press, 2010, at para. 3.0.2; and Susy Frankel, Intellectual Property in New Zealand, 2nd edn, Wellington, New Zealand: LexisNexis Butterworths, 2011, at p. 210 [hereinafter Frankel, IP in NZ]. See also Berne Convention, Articles 8, 9(1), 11(1), 11bis, 11ter, 12, 14(1) and 14 ter; and Copyright Act 1994 (NZ), s. 16.

134 TRIPS Agreement, Articles 13 and 14.6.

135 Berne Convention, Articles 9, 10 and 10bis.

136 The limitations and exceptions set out in the TRIPS Agreement and the Berne Convention are discussed in J. Adrian Sterling, World Copyright Law, 2nd edn, London: Sweet \& Maxwell, 2003, at para. 22.10; Peter van den Bossche, The Law and Policy of the World Trade Organization, 2ed, New York, Cambridge University Press, 2008, at pp. 766-769; and Paul Goldstein and Bernt Hugenholtz, International Copyright. Principles, Law, and Practice, 2nd edn, New York: Oxford University Press, 2010, at pp. 364-367.

137 Frankel, IP in NZ, supra note 133, at p. 210, who stated: "From the copyright owner's perspective these [copyright rights] are exclusive rights. From everyone else's perspective they are restricted acts."

138 TRIPS Agreement, Article 9.1.

139 Goldstein and Hugenholtz, supra note 136, at pp. 42-43. See also WTO, Panel Report, China - Measures Affecting the Protection and Enforcement of Intellectual Property Rights, WTO Doc. WT/DS-362/R, adopted 20 March 2009. 
recommendation that private use should not be restricted in any way. This raises the question of what this means for the spiritual offence felt, if the work and copies continue to exist, though no longer used in public. Does merely restricting public and/or commercial use achieve the aim of protecting the kaitiaki interest?

Under international copyright law, there does not appear to be anything to prevent the Tribunal recommending (or the Government adopting) something more pervasive on the expression maker, such as destruction of the work (and copies thereof). Moral rights are protected under the Berne Convention. ${ }^{140}$ These protect the personality of the author and are stipulated in Article 6bis(1), ${ }^{141}$ which states that authors have the right to "object to any distortion, mutilation or other modification, or other derogatory action in relation to the said work, which would be prejudicial to his honour or reputation". ${ }^{142}$ Notably, the destruction of a work is not covered under the Berne Convention or New Zealand copyright law, only alterations. This is because - though named "moral rights" - the interests of "honour or reputation" are different from "moral" or "spiritual" interests, the latter of which are wider. ${ }^{143}$ Furthermore, the Berne Convention and the New Zealand Copyright Act both protect the reputation of an author rather than the "integrity" of a work. ${ }^{144}$ This means that it is not enough that the author does not like what has been done, rather the rights are viewed from an objective standpoint, requiring that what has been done to a work reflects badly on the author from the perspective of the public, implicitly necessitating that the alterations to the work can still be observed by the public. In other words, under the Berne Convention, a work that is destroyed can no longer reflect anything about the author and so cannot be said to infringe on the author's moral rights.

What may be a ground to prevent the destruction of a work is that the author's private use of his/her work could be protected under the right from interference with one's privacy, family and home, according to Article 17 of the UN International Covenant on Civil and Political Rights (CCPR). ${ }^{145}$ The notion of "privacy" in the CCPR is by no means well-delineated, ${ }^{146}$ but "home" has been outlined very broadly to be where a person resides or carries out his/her usual occupation. ${ }^{147}$ Regardless of the vagueness of "privacy", it is perceivably possible that the use of a taonga work, taongaderived work or mätauranga Māori by an individual in his/her own home could be covered by the right to privacy or home. Of course, the right encapsulated in Article 17 is not unlimited and can be restricted if done non-arbitrarily and lawfully. To be

140 Berne Convention, Article 6bis. The UN International Covenant on Economic, Social and Cultural Rights also protects the moral interests of authors; 993 UNTS 3; 6 ILM 360 (adopted on 16 December 1966, entered into force 3 January 1976), Article 15.1(c) and 15.2.

141 Though the TRIPS Agreement adopts into it Articles 1-21 of the Berne Convention, Article 6bis is specifically excluded; TRIPS Agreement, Article 9.1. See also Mira T. Sundara Rajan, Moral Rights. Principals, Practice and New Technology, New York: Oxford University Press, 2011, at pp. 250-258. This means that moral rights are not enforceable through the WTO dispute settlement process. Nevertheless, New Zealand has Berne-Conventionlike moral rights implemented into the Copyrights Act 1994 (NZ), ss 94-119; derogatory treatment is dealt with in ss 98-101.

142 New Zealand law covers additions, alterations or adaptations; Copyright Act 1994 (NZ), s. 98(1)(a).

143 WIPO, Intergovernmental Committee on Intellectual Property and Genetic Resources, Traditional Knowledge and Folklore, Secretariat, 'Glossary of Key Terms Related to Intellectual Property and Traditional Cultural Expressions', (WIPO Doc. WIPO/GRTKF/IC/18/INF/7, 2011), at p. 22.

144 Sundara Rajan, supra note 141, at pp. 45-49; Sundara Rajan argues against the approach that the Berne Convention has taken in favouring author's reputation over the integrity of the work.

145 CCPR, supra note 93, Article 17.

146 See Joseph, Schultz and Castan, supra note 93, paras 16.01-16.02.

147 UN, Human Rights Committee (UN HRC), 'The Right to Respect of Privacy, family, Home and Correspondence, and Protection of Honour and Reputation' (Article 17)', CCPR General Comment No. 16 (UN HRC Doc. HRI/GEN/1/Rev.9 (Vol. I) p. 191, 1988), para. 5. 
"lawful", the restriction must be based in law and "must comply with the provisions, aims and objectives" of the CCPR. ${ }^{148}$ Furthermore, "relevant legislation must specify in detail the precise circumstances in which such interferences may be permitted." 149 Interferences provided for in law can still be "arbitrary". ${ }^{150}$ The requirement of nonarbitrariness is to ensure that interferences are "reasonable in the particular circumstances", 151 where "reasonable" means that interferences must be "proportional to the end sought and necessary in the circumstances of any given case." 152

The author here suggests that - if legislation is adopted to prevent the offensive use of taonga works, taonga-derived works or mätauranga Māori in public - it should also allow for certain specific circumstances when the destruction of the offensive work and any copies could be ordered by the recommended commission. For CCPR-consistency, the circumstances would have to be well-defined and drafted such that the application would be limited, in order to ensure that the interference on the right to privacy/home is proportional and necessary. Thus, in most cases, an order for such destruction is not envisaged. Such destruction orders should only be justifiable if the continued existence of the work and its copies would strongly and detrimentally affect the kaitiaki relationship. This means that destruction could only be ordered for works using taonga works or mätauranga Māori and not taonga-derived works. Given the invasiveness on the right to privacy/home (a highly valued right), the evidentiary burden of proof of the effect on the kaitiaki relationship would need to be high; there must be a real and welldocumented aspect of tikanga or te ao Māori - relating to the kaitiaki relationship - that would be seriously breached by the continued existence of the work and copies thereof. This would allow for some objectivity, which is important given the consequential breach of a basic human right.

\subsubsection{Industrial Design}

In New Zealand, industrial designs can be registered ${ }^{153}$ and so can be deregistered. TRIPS requires that industrial designs that are "new or original" be protected. ${ }^{154}$ There are only two available limitations, firstly that Member States may find a design not "new or original" if it does not significantly differ from the prior art and, secondly, designs that are dictated essentially by technical or functional considerations may be rejected. ${ }^{155}$ Thus, prohibiting or removing registration on the basis of offensive use of Māori cultural heritage would not be TRIPS-compliant. However, as with copyright, industrial design rights do not endow the owner with positive rights, but rather rights to prevent third parties from performing certain acts. ${ }^{156}$ Hence, there is nothing to stop the legislator from preventing an industrial-design owner from using his/her industrial design, if there is offensive use of Māori cultural heritage.

\footnotetext{
Ibid., para. 3 .

Ibid., para. 8 .

Ibid., para. 4.

Ibid., para. 4.

Toonen v Australia (1994) Comm. No. 488/92, at para. 8.3 (HRC).

Designs Act 1953.

TRIPS Agreement, Article 25.1.

TRIPS Agreement, Article 25.1.

56 TRIPS Agreement, Article 26.1.
} 


\subsubsection{Trade Marks}

The recommendations made by the Tribunal in the Wai 262 report, so far as they impact on trade mark law, would only affect whether a trade mark could be registered and maintain registration. The TRIPS Agreement does not make any general or specific exceptions to registration of trade marks. Article 15.2 states that Members may deny registration "provided that they do not derogate from the provisions of the Paris Convention (1967)." There is nothing in the Paris Convention that says anything about an exception to registration for marks that are offensive. The only remotely relevant article is Article 6quinquies, which allows signatory countries to refuse to register trade marks that have been registered in another signatory country (which they are normally obliged to do) if the marks are "contrary to morality or public order, in particular of such a nature as to deceive the public." 157 Though the concepts of "morality" and ordre public have been raised here, it is done in a very specific manner with limited application. The terms are not used in any other context in the Paris Convention.

Provisions that allow trade mark applications to be rejected on the grounds of offensiveness (whether specifically to the Māori or the population general) or breach of a kaitiaki relationship could then be considered to "derogate" from the provisions in the Paris Convention and not be TRIPS compliant. However, this is not the case, as the purpose of the Paris Convention was to create a "Union" and ensure national treatment for the purposes of industrial property. Indeed, it does not at all regulate the way in which applications are filed or in which registration is executed. That the Convention does not mention any exceptions to registration is only consistent with this. Therefore, under TRIPS and the Paris Convention, states are free to formulate their registration processes as they see fit and the rejection of applications on the basis of offensiveness or impact on the kaitiaki relationship is compliant.

If the proposed commission were only able to enjoin use of marks registered prior to the enactment of new legislation, rather than have them deregistered (i.e. nonretroactivity), this would not have any affect on the exclusive rights connected to a registered trade marks. As with copyright, trade mark law gives the right to owners to prevent third parties from using the registered mark (or similar marks) in trade. It does not guarantee that the owner him- or herself will use the mark in trade. Thus, the proposed mechanism would be consistent with TRIPS in this regard.

\section{FinAl ThOUghtS}

Like the UNDRIP, which New Zealand adopted in April 2010,158 the Wai 262 report is not binding. Nevertheless, also like the Declaration, it has huge symbolic and political force. At the time of writing, the New Zealand Government was still considering the report. Attorney-General Christopher Finlayson stated that the report

Paris Convention, Article 6quinquies.B.3.

158 UNDRIP, supra note 119; and Pita Sharples (Māori Party Co-Leader), 'Supporting UN Declaration Restores NZ's Mana', Press Release (20 April 2010), available online at http://www.beehive.govt.nz/release/supporting+un+declaration+restores+nz039s+mana. Addressing whether the Wai 262 report is consistent with the UN Declaration is outside the confines of the purposes of this paper, but is well-worth its own discourse. 
would give "much food for thought". ${ }^{159} \mathrm{He}$ further noted that, though there is some emerging international consensus to assist the Government, there were other areas that were novel and any response should not be rushed. ${ }^{160}$ Given the importance of the issues involved in the report and the length of time taken for its delivery, much was expected from it. ${ }^{161}$ Opinions on the report have been mixed, with some viewing it as potentially conceding to the Māori too much, 162 or contradicting New Zealand democratic traditions. ${ }^{163}$ Whereas others (particularly the claimants) have declared their dissatisfaction at the half-way and precautionary nature of the recommendations, ${ }^{164}$ stating that the participatory character of many of the recommendations (rather than complete control) do not necessarily mean more power.

The author here does not agree with either view, but is instead optimistic with the compromise and balance developed in the report, which reflects the very nature of the Treaty of Waitangi. As pointed out throughout the paper, the report on occasion lacked in clarity and preciseness. However, this is something that can be worked on. Particular attention must be made to the definition of key terms to maximise the objectivity and certainty of the recommended process and to ensure that the interface with IP is as smooth as possible. Fine-tuning definitions should be done in guidelines as well as at the legislative level, to provide for the required flexibility. Though the Tribunal recommended the creation of external best-practice guidelines for use by potential users of Māori cultural heritage, internal guidelines should also be produced for use by the proposed commission and should be freely available to the public for transparency.

Overall, a positive note should be made of the report generally seeking to balance the interests of all concerned parties, while at the same time taking into account the modern context that the Treaty guarantees must be interpreted in and the ultimate goal of advancing New Zealand socially and economically; a by no means easy feat. The Māori (and many indigenous peoples) have often argued that they do not want

159 Belinda McCammon, 'Govt Considers Wai 262 Claims Report', stuff.co.nz National (2 July 2011), available at http://www.stuff.co.nz/national/politics/5224263/Govt-considers-Wai-262-claims-report.

160 Ibid. Prime Minister John Key made similar statements that the Government would not be rushed; Kate Chapman and Belinda McCammon, 'Govt Take Time to Considering Wai 262 Report', stuff.co.nz National (4 July 2011), available at http://www.stuff.co.nz/national/politics/5228332/Govt-to-take-time-considering-Wai262-report.

161 See, for example, Lord, supra note 24, at pp. 41-42.

162 'Editorial: Caution the Right Approach to Report', The Dominion Post (7 July 2011), available online at http://www.stuff.co.nz/dominion-post/comment/5245734/Editorial-Caution-the-right-approach-to-report. For an extreme view, see Muriel Newman, 'Wai 262 Empowers Māori Elite' (2011) New Zealand Centre for Political Research, 284, available at http://www.nzcpr.com/Weekly284.pdf. Newman's article borders on being propaganda-like and racist in nature. In the least, it is dangerously provocative. It is clear that she either did not read the full report before writing her piece, or did not grasp the intention behind the recommendations of the Waitangi Tribunal. Yet, states that the claimants have a "race-based lust for power and control" (at p. 1), that non-Māori "are being increasingly marginalised by the cunning strategies of a greedy tribal elite" (at p. 1); and are treating non-Māori as fools by claiming spirituality that does not exist (at p. 2). Moreover, she places fire under fears already existent in mainstream New Zealand that any rights given to Māori will create a "country permanently divided by race, with a Maori aristocracy based on privilege." Māori lawyer Joshua Hitchcock stated that her opinion was an "utter disgrace" and "nothing more than an attempt to spread fear through the Pakeha population that [the Wai 262] Report will be the catalyst for the takeover of New Zealand by a Maori Oligarchy”; Joshua Hitchcock, 'Wai 262: Initial Thoughts', Māori Law and Politics (2 July 2011), available at http://roiamaori.wordpress.com/2011/07/02/wai-262-initial-thoughts/.

163 Such as Act Party Leader Don Brash; Tova O'Brien, 'Iwi Shouldn't Get Special Treatment with Wai 262 Brash', 3 News (2 July 2011), available at http://www.3news.co.nz/Iwi-shouldnt-get-special-treatment-withWai-262---Brash/tabid/423/articleID/217335/Default.aspx.

164 Rahui Katene, 'Māori Should Dare to Take the Leap of Faith in Planning for Survival', The Dominion Post (12 July 2011), available online at http://www.stuff.co.nz/dominion-post/comment/5269828/Maori-should-dare-totake-the-leap-of-faith-in-planning-for-survival. 
"ownership" over their cultural and intellectual property, but rather a real voice in decision-making ${ }^{165}$ and the ability to exercise their roles and mana as kaitiaki. It has been difficult for colonised states to perceive of how to accommodate the idea of stewardship without also bestowing ownership. The "half-way nature" of stewardship has made states and opponents think and act as if there are either no rights or ownership, which has made states tend towards the former. Through embracing kaitiakitanga as recognised through tino rangatiratanga in Article 2 of the Treaty of Waitangi, the Tribunal has introduced the recognition of a non-typically-Western concept into the realm of property law (both real and intellectual). Moreover, the core mechanism presented by the Tribunal is a procedural approach, which - as has been concluded by Christoph B. Graber - is the most suitable form for a solution involving the interface between the two worldviews of the Māori, on one side, and of the Western world, on the other. ${ }^{166}$ The encompassing nature of the recommendations could have huge ramifications within New Zealand and even internationally, as other states and indigenous peoples around the world look to see what will be implemented.

Peter Dengate-Thrush has noted that, rather than being economic, the "greatest part of the value to the claimants may well lie in a restoration of 'mana' said to have been lost." 167 The mechanisms proposed by the Tribunal would allow for this restoration. As stated by Māori Party MP Rahui Katene, "with the receiving of this report - [now] is the time to both reaffirm our enduring spirit of commitment as well as to pave a new pathway forward to write a better history" and "[o]ur next steps are crucial in creating the partnership which truly reflects the constitutional promises made in the Treaty. Our future depends on it". 168

Mead, 'Indigenous Rights to Land and Biological Resources', supra note 123, at p. 1.

166 Christoph B. Graber, 'Institutionalization of Creativity in Traditional Societies and in International Trade Law', in Shubha Ghosh (ed.), Creativity, Law and Entrepreneurship, Cheltenham, UK: Edward Elgar, 2010, pp. 234-263, at 251-252; and Christoph B. Graber, 'Stimulating Trade and Development of Indigenous Cultural Heritage by Means of International Law: Issues of Legitimacy and Method', Christoph B. Graber, Karolina Kuprecht and Jessica C. Lai (eds), International Trade in Indigenous Cultural Heritage: Legal and Policy Issues, Cheltenham, UK: Edward Elgar, 2012 (forthcoming).

167 Dengate-Thrush, supra note 2, at p. 309. See also Lord, supra note 24, at p. 35, who stated that having tino rangatiratanga in their traditional cultural heritage is about restoring mana, cultural integrity and dignity, and strengthening cultural identity.

168 Rahui Katene (Māori Party MP), 'Wai 262', Māori Party Speech (2 July 2011), available online at http://www.scoop.co.nz/stories/PA1107/S00024/speech-wai-262-rahui-katene.htm. 


\section{APPENDIX: SUMMARY OF THE TRIBUNAL'S RECOMMENDATIONS FOR TAONGA WORKS, TAONGA-DERIVED WORKS AND MĀTAURANGA MĀORI}

\begin{tabular}{|c|c|c|c|}
\hline & taonga works & $\begin{array}{l}\text { taonga-derived } \\
\text { works }\end{array}$ & mātauranga Māori \\
\hline $\begin{array}{l}\text { Private } \\
\text { Non-Commercial Use }\end{array}$ & Unchallengeable & Unchallengeable & Unchallengeable \\
\hline $\begin{array}{l}\text { Public } \\
\text { Non-Commercial Use } \\
- \\
\text { Not } \\
\text { Offensive/Derogatory }\end{array}$ & Unchallengeable & Unchallengeable & Unchallengeable \\
\hline $\begin{array}{l}\text { Public } \\
\text { Non-Commercial Use } \\
\text { - } \\
\text { Offensive/Derogatory }\end{array}$ & $\begin{array}{l}\text { Challengeable by } \\
\text { anyone. } \\
\text { Remedy at the } \\
\text { discretion of the } \\
\text { recommended } \\
\text { commission }\end{array}$ & $\begin{array}{l}\text { Challengeable by } \\
\text { anyone. } \\
\text { Remedy at the } \\
\text { discretion of the } \\
\text { recommended } \\
\text { commission }\end{array}$ & $\begin{array}{l}\text { Challengeable by } \\
\text { anyone. } \\
\text { Remedy at the } \\
\text { discretion of the } \\
\text { recommended } \\
\text { commission }\end{array}$ \\
\hline $\begin{array}{l}\text { Public } \\
\text { Commercial Use } \\
- \\
\text { Not } \\
\text { Offensive/Derogatory }\end{array}$ & $\begin{array}{l}\text { Challengeable by } \\
\text { kaitiaki for future } \\
\text { use (if no pre- } \\
\text { existing IPRs). } \\
\text { Right to } \\
\text { consultation and } \\
\text { possibly a right to } \\
\text { consent to use. }\end{array}$ & Unchallengeable & $\begin{array}{l}\text { Challengeable by } \\
\text { kaitiaki for future } \\
\text { use (if no pre- } \\
\text { existing IPRs), if } \\
\text { "closely held" and } \\
\text { there is an } \\
\text { identifiable kaitiaki. } \\
\text { Right to } \\
\text { consultation and } \\
\text { possibly a right to } \\
\text { consent to use. }\end{array}$ \\
\hline $\begin{array}{l}\text { Public } \\
\text { Commercial Use } \\
\text { - } \\
\text { Offensive/Derogatory }\end{array}$ & $\begin{array}{l}\text { Challengeable by } \\
\text { anyone. } \\
\text { Remedy at the } \\
\text { discretion of the } \\
\text { recommended } \\
\text { commission }\end{array}$ & $\begin{array}{l}\text { Challengeable by } \\
\text { anyone. } \\
\text { Remedy at the } \\
\text { discretion of the } \\
\text { recommended } \\
\text { commission }\end{array}$ & $\begin{array}{l}\text { Challengeable by } \\
\text { anyone. } \\
\text { Remedy at the } \\
\text { discretion of the } \\
\text { recommended } \\
\text { commission. }\end{array}$ \\
\hline
\end{tabular}




\section{GLOSSARY}

Ahi kā

Atua

Haka

Hapū

Heitiki

Hui

Iwi

Kaitiaki

Kaitiakitanga

Karakia

Kaumatua

Kawanatanga

Kōrero

Koru

Kowhaiwhai

Mana
The "long burning fire of occupation" (Hirini M. Mead, Landmarks, Bridges and Visions: Aspects of Māori Culture, Wellington: Victoria University Press, 1997, at p. 264). Traditionally, it applied only to land, but the contemporary view is that this concept can extend beyond just land, and is about meeting one's tribal obligations and maintaining their connections to the Māori world (T. Kāretu, 'The Clue to Identity' (1990) New Zealand Geographic, 5, pp. 112-117, at p. 112).

Gods.

Māori posture dance.

A sub-division of iwi (clans within an iwi). Membership is determined by genealogical descent and a hap $\bar{u}$ is made up of a number of whānau.

Carved figure, image, a neck ornament usually made of greenstone and carved in an abstract form of a human.

A gathering, assembly or meeting.

These are Māori tribes, consisting of several related hapū (clans or descent groups).

Someone who has the mana to be a trustee, minder, guard, custodian, guardian or keeper over something that is taonga.

Māori stewardship or guardianship over their people lands, villages and treasures. The conservation ethic embodied in the practice of Kaitiakitanga is important for the sustainable management of natural and physical resources. The use, management, and control of these resources are carried out to the mutual benefit of people and resources.

Incantations and prayers.

Elders.

Governance.

Narrative, story, discussion or conversation.

A shape based on an unfurling fern frond, common in Māori designs and art work.

Māori scroll painting, painted scroll ornamentation commonly used on meeting house rafters.

This is authority, control, influence, power, prestige, psychic force. There are three forms of mana: mana atua - God given power; mana tüpuna - power from ancestors; mana tangata authority from personal attributes. (See Margaret Mutu, Te 
Whānau Moana: Nga kaupapa me nga tikanga/ Customs and Protocols - The Teachings of McCully Matiu, Auckland:

Redbooks, 2003, p. 156).

Manākitanga Nurturing relationships and looking after people.

Māoritanga

A term which conceptualises "Māoriness" and encapsulates elements of traditional Māori expressions considered to be essential to Māori culture.

Marae

Sacred places, which serve both a religious and social purpose in pre-Christian Polynesian societies.

Mātauranga

Māori knowledge; traditional knowledge of cultural practice;

Māori the body of knowledge originating from Māori ancestors, including the Māori world view and perspectives, Māori creativity and cultural practices.

Mauri

The life force.

Moko

Māori facial tattoo.

Mokopuna

Grandchild or descendent.

Mōteatea

Song poetry or chant.

Ngāngara (also

ngārara)

Ngā taonga

tūturu

insect, creepy-crawly, reptile

Objects that relate to Māori culture, history or society.

Noa

To be free of Tapu. The tapu of taonga sometimes needs to be removed temporarily before people can make use of them. Karakia are important for the removal of tapu from taonga, rendering them noa.

Pākehā

A name used to refer to non-Māori, usually of European decent.

Pitau See koru.

Rangatiratanga See Tino rangātiratanga.

Taiaha

Traditional Māori weapon.

Ta moko

The art of Māori tattooing.

Tāngata whenua

A term sometimes used by the Māori to self-identify. In its broadest sense, it means "people of the land", so is also used to mean "indigenous people".

Tangi Funeral service.

Taniko Māori weaving.

Taonga Treasures or highly prized possessions or holdings; sacred.

Tapu

To be sacred (the opposite of noa). People, objects or places can be tapu. All taonga are tapu.

Te ao Māori The Māori worldview. Literally "the Māori world". 
Te ao Pākehā

Te reo Māori

Tikanga Māori

Tiki

Tino rangatiratanga

Tipuna (also tipuna, tupuna, tūpuna)

Tohunga

Utu

Wahi tapu

Waka

Whakairo iwi

Whakairo kohatu

Whakairo rakau

Whakapapa

Whānau

Whanaungatanga
The non-Māori world view.

The Māori language.

"Māori tools of thought and understanding that help organise behaviour" (Hirini M. Mead, Tikanga Māori: Living by Māori Values, Wellington: Huia Publishers, 2003, at p. 12), or a "Māori way of doing things" (New Zealand Law Commission, Māori Custom and Values in New Zealand Law, Wellington: NZLC, 2011 at p. 17). They are subject to interpretation, there are tribal variations and there is fluidity in their application.

See heitiki.

Sovereignty, chieftainship, self-determination.

Ancestors

Priests; experts in Māori medicine and spirituality.

This is about reciprocity in relationships and the balancing of social relationships.

Sacred places, "in the traditional, spiritual, religious, ritual, or mythological sense" (Historic Places Act 1993 (NZ)).

Māori canoe.

Māori bone carving.

Māori stone carving.

Māori wood carving.

Whakapapa represents more than lineage and genealogy, but also connects Māori existence to the atua (gods), creation and all life and represents the inheritance Māori receive from descent. It is encompasses the view of existence itself and the relationship between this and the natural world.

This means extended family and includes anyone connected by blood, not matter how distantly connected.

This is one of the most pervasive Māori values and it stresses the importance of maintaining relationships, or creating meaningful relationships with people. The nature of this kinship relationship determines people's rights, responsibilities, and obligations in relation to the use, management, and control of taonga of the natural world. Whanaungatanga determines rights and use, and responsibility to sustainably manage particular resources.

Note. There is an online Māori to English dictionary, available at http://www.maoridictionary.co.nz/ 